\title{
Output Comovement and Inflation Dynamics in a Two-Sector Model with Durable Goods: The Role of Sticky Information and Heterogeneous Factor Markets
}

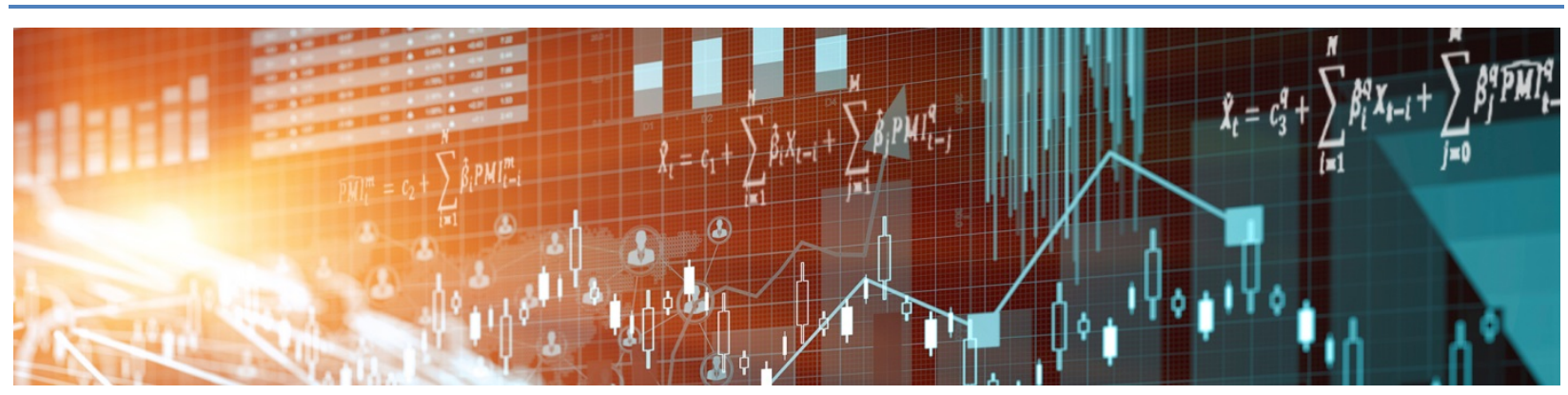

by Tomiyuki Kitamura and Tamon Takamura

Bank of Canada staff working papers provide a forum for staff to publish work-in-progress research independently from the Bank's Governing Council. This research may support or challenge prevailing policy orthodoxy. Therefore, the views expressed in this paper are solely those of the authors and may differ from official views of the Bank of Canada or Bank of Japan. No responsibility for them should be attributed to the Bank of Canada and/or the Bank of Japan. 
Bank of Canada Staff Working Paper 2016-36

July 2016

\title{
Output Comovement and Inflation Dynamics in a Two-Sector Model with Durable Goods: The Role of Sticky Information and Heterogeneous Factor Markets
}

\author{
by \\ Tomiyuki Kitamura \\ Bank of Japan \\ tomiyuki.kitamura@boj.or.jp
}

Tamon Takamura

Financial Stability Department

Bank of Canada

Ottawa, Ontario, Canada K1A 0G9

ttakamura@bankofcanada.ca 


\section{Acknowledgements}

The authors would like to thank Jason Allen, Gino Cateau, Geoffery Dunbar, Bill Dupor, Paul Evans, Stefano Gnocchi, Yuriy Gorodnichenko, Aubhik Khan, Christien Mitchell,

Wataru Miyamoto, Yaz Terajima and Julia Thomas for helpful comments and discussions. 


\begin{abstract}
In a simple two-sector New Keynesian model, sticky prices generate a counterfactual negative comovement between the output of durable and nondurable goods following a monetary policy shock. We show that heterogeneous factor markets allow any combination of strictly positive price stickiness to generate positive output comovement. Even if the prices of durable goods are flexible, adding sticky information ensures that the output of both sectors moves in the same direction. Furthermore, we find that the combination of sticky information and heterogeneous factor markets produces humpshaped responses in both sectoral output and inflation, as observed in a vectorautoregression analysis. In contrast to backward indexation to past inflation, which is often assumed in the literature, sticky information leads to a hump-shaped response in the inflation of flexibly priced goods. Finally, the estimated information stickiness through the minimum-distance estimation method suggests that information rigidity is stronger in residential investment than nondurable goods and services.
\end{abstract}

JEL classification: E31, E32, E52

Bank classification: Inflation and prices; Transmission of monetary policy

\title{
Résumé
}

Dans un modèle simple de type nouveau keynésien à deux secteurs, la rigidité des prix engendre une covariation négative contrefactuelle de la production de biens durables et de biens non durables à la suite d'un choc monétaire. Nous montrons que des marchés de facteurs hétérogènes permettent toute combinaison de rigidité des prix strictement positive pour générer une covariation de production positive. Même si les prix des biens durables sont flexibles, l'ajout d'information rigide fait évoluer la production des deux secteurs dans le même sens. De plus, nous constatons qu'une combinaison d'information rigide et de marchés de facteurs hétérogènes engendre des réactions dynamiques en forme de bosse dans le cas de la production et de l'inflation sectorielles, comme il a été observé dans une analyse de vecteurs autorégressifs. Par contraste avec l'indexation rétrospective sur l'inflation passée, souvent présumée dans la littérature, la rigidité de l’information produit une réaction dynamique en forme de bosse pour l'inflation des biens à prix flexible. Enfin, les résultats issus de l'application de la méthode d'estimation de la distance minimale donnent à penser que l'information est plus rigide dans le cas de l'investissement résidentiel que dans celui des biens non durables et des services.

Classification JEL : E31, E32, E52

Classification de la Banque : Inflation et prix; Transmission de la politique monétaire 


\section{Non-Technical Summary}

Empirical evidence shows that the output of nondurable and durable goods responds in the same direction after an unexpected change in monetary policy. Moreover, the price inflation, as well as the output of these goods, exhibits a delayed response. However, the predictions of a simple two-sector sticky-price model with durable and nondurable goods are not consistent with these observations: output in each sector moves in opposite directions and the peak response in inflation in each sector occurs on impact of the shock. Accounting for these dynamics is important for improving our understanding of how the effects of monetary policy are transmitted through different sectors of the economy.

This paper examines whether information stickiness (Mankiw and Reis 2002) and the heterogeneity of production factors help resolve the output comovement anomaly in a two-sector sticky-price model and simultaneously explain the observed persistence in sectoral inflation and output. Sticky information allows firms to update information sporadically, which captures costs associated with firms' decision-making processes. Labour and capital are firm-specific production factors and prevent factor prices from equalizing immediately across sectors. These restrictions in our model interact and dampen the disparity of prices, which induces consumers to demand both types of goods rather than substituting between the two.

We find that our model generates positive comovement of sectoral output, as well as a delayed response of inflation and output in each sector. Moreover, the implied responses of our model are broadly consistent with the empirical evidence when matched with the data. Although existing studies have suggested other mechanisms to solve the output comovement problem, this model can simultaneously explain delayed responses in sectoral inflation as well as output. Furthermore, in contrast to backward indexation to past inflation, a frequently used assumption in sticky-price models to generate a delayed inflation response, our model can generate the desired response without counterfactually assuming that all prices have to change every period. In addition, the delayed responses arise naturally in our model regardless of assumed price stickiness, whereas sufficiently strong price stickiness is required for the backward indexation rule to work. 


\section{Introduction}

Durable goods consumption and residential investment are volatile and interest-rate-sensitive components of GDP (Erceg and Levin 2005, 2006). In recent years, mainly due to the Great Recession and the role of housing in generating it, there has been a renewed interest in studying the role of durable goods in explaining economic booms and prolonged recessions. In order to understand how these sectors affect business cycles and the monetary policy transmission mechanism, macroeconomists have made efforts to develop dynamic stochastic general-equilibrium (DSGE) models that explicitly take into account the production and consumption of durable goods and housing. The paper by Barsky, House and Kimball (BHK 2007) is one such contribution, which examines the propagation mechanism of a monetary policy shock in a two-sector DSGE model featuring time-dependent sticky prices, à la Calvo, and long-lived durable goods. They find that a plainvanilla two-sector sticky-price model with durable goods exhibits counterfactual output dynamics. For example, if the prices of durable goods are flexible and those of nondurable goods are sticky, the model predicts that the output of durable goods contracts sharply while that of nondurable goods increases following an unexpected monetary easing. ${ }^{1}$

However, the theoretical predictions of their model are inconsistent with the empirical evidence. $^{2}$ For example, Erceg and Levin $(2005,2006)$ use vector-autogression (VAR) analysis to show that consumer durables plus residential investment, as well as other components of GDP, decrease simultaneously following an unexpected monetary tightening. Moreover, Section 2 of our paper shows that inflation and output of residential investment, durable goods, and nondurable goods plus services (NDSV) exhibit hump-shaped responses, reaching their peak with a delay. While existing models have difficulty simultaneously accounting for the comovement of sectoral output as well as the delayed responses in sectoral inflation and output, capturing both of these features in a DSGE model is important in that these sectoral variables may have welfare implications in a multiple-production-sector economy (Aoki 2001, Erceg and Levin 2006).

This paper examines whether information rigidities and the heterogeneity of production factors can resolve the negative comovement problem. In addition, based on findings from VAR studies, we evaluate to what extent these frictions can help explain delayed responses of inflation and output in each sector following a monetary policy shock. For this purpose, we add sticky information of the type considered by Mankiw and Reis (2002) to both types of goods ${ }^{3}$ and assume that labour and

\footnotetext{
${ }^{1}$ Furthermore, their analysis shows that even if nominal price rigidities are identical in both sectors, increases in aggregate output are almost entirely explained by durable goods, while the production of nondurable goods has an immaterial effect.

${ }^{2}$ The contribution of BHK (2007) is the finding of counterfactual predictions of New Keynesian two-sector models with durable goods.

${ }^{3}$ Dupor et al. (2010) present a model featuring both sticky information and sticky prices in a single-sector economy. We build on their work to develop a two-sector version of that model with durable goods.
} 
capital are firm-specific as in Woodford (2003). In BHK (2007), the marginal cost of production increases equally for both goods following an expansion in aggregate demand due to homogeneous production factors. Along with the difference in price stickiness between the two goods, this leads to a sharp disparity in the relative price of the two types of goods, which induces consumers to substitute relatively expensive goods with inexpensive goods whose prices are bound by price stickiness. An important role of the frictions proposed in this paper is to dampen large changes in the relative price of goods, and thus, mitigate the substitution effect of monetary policy on the demand for both types. First, heterogeneous factors of production imply that firms in the two sectors face different marginal costs. Given that firms adjust prices based on these costs, the relative price change between the two goods will be limited, even if price stickiness is different across sectors. ${ }^{4}$ Second, sticky information allows only a fraction of firms to update their information in each period, leading to a gradual change in the average price of goods in each sector. ${ }^{5}$

Through the lens of our model, we examine quantitatively the effects of these frictions on the comovement of sectoral output following an unexpected monetary easing. In addition, we evaluate the joint implications for the persistence of sectoral inflation and output. Finally, to evaluate the extent to which our two-sector model can quantitatively explain the VAR responses in sectoral output and inflation, we apply the minimum-distance estimation method as in Christiano et al. (2005). Specifically, we estimate a subset of structural parameters, including the degree of information stickiness in each sector, to minimize the distance between the model-implied and VAR impulse responses to a monetary policy shock. Target variables in this exercise are residential investment, the output of NDSV, and the inflation rates of these two variables. Following the argument in BHK (2007), residential investment represents flexibly priced durable goods since house prices are negotiable.

The main findings of this paper are as follows. First, factor market heterogeneity reduces the substitution effect of monetary policy by breaking the tight link between marginal costs in the two sectors. For example, suppose that there is a monetary expansion. Heterogeneous factor markets insulate the sector that produces relatively flexibly priced goods from higher factor prices emanating from an output expansion in the other sector due to price stickiness. This has an important implication for the effect of nominal rigidities on output comovement. For example, we find that any combination of strictly positive price stickiness across two sectors results in positive output

\footnotetext{
${ }^{4}$ The firm-specificity of production factors captures the fact that wages, for example, do not equalize immediately across firms and industries when workers change jobs. This is consistent with the empirical evidence that workers separated from firms suffer large and long-term losses even when they find new jobs in similar firms (Jacobson et al. 1993).

${ }^{5}$ Zbaracki et al. (2004) document that large U.S. manufacturing firms face managerial costs associated with price adjustments, which include the cost of information gathering, decision making, and communication within the firm. Sticky information in Mankiw and Reis (2002) is a reduced-form approach that captures this effect. In state-dependent models, Reis (2006a,b) and Gorodnichenko (2008) provide the micro foundations for sticky information.
} 
comovement. ${ }^{6}$ This result is in contrast to the baseline model in BHK (2007) with homogeneous factors, in which many combinations of price stickiness generate negative output comovement.

Similarly, adding sticky information to both goods, in combination with heterogeneous factors, stimulates the demand for both goods following a monetary expansion. This is because the optimal prices set by firms change only gradually since firms acquire and process information infrequently. We show that a mild degree of information stickiness gives rise to a relatively large increase in the production of goods following a monetary easing, even if prices are completely flexible.

Moreover, sticky information helps generate hump-shaped sectoral inflation responses following a monetary policy shock, as observed in the data. This is a particularly attractive feature of sticky information that distinguishes it from sticky prices. Whereas firms that are subject to sticky prices choose the same optimal price, reflecting anticipated effects from having to hold the same price in the future, firms with sticky information determine plans for future prices based on currently available information. This allows firms to react more gradually over time to changes in the economy, and thus leads to a delayed response in inflation.

It is known that backward indexation to past inflation can also generate hump-shaped responses of inflation to a monetary policy shock. However, the backward indexation is counterfactual in that it goes against the micro evidence that some prices are sticky. Moreover, it is unable to generate a hump-shaped sectoral inflation response if goods are flexibly priced or exhibit limited price stickiness in that sector, ${ }^{7}$ because the indexation rule is applied to firms that are not allowed to post new prices. Sticky information can co-exist with sticky prices without causing these issues. This implies that sticky information is a more relevant explanation for the hump-shaped sectoral inflation response.

Finally, through an empirical assessment of our model, we find that the model-implied responses match empirical responses well. That is, the model-implied responses in the four variables mentioned above broadly capture the hump-shaped patterns of VAR responses immediately after a monetary shock. Our estimates of sticky information imply that, on average, firms update their information every 6 to 7 months in the nondurable goods sector, and every 11 to 12 months in the housing sector. Using data on professional forecasters, Coibion and Gorodnichenko (2015) find that the estimated degree of information rigidity is larger in the housing sector than in the consumption goods sector. Our results are consistent with this finding.

It is worth noting that both sticky information and firm-specific factors are crucial elements in

\footnotetext{
${ }^{6}$ If durable goods prices are completely flexible, for example, its sectoral output does not change in response to a monetary policy shock. In this case, positive comovement occurs if we further allow for complementarity of goods. Moreover, a mild degree of complementarity between the two goods could be sufficient, in contrast to the result in BHK (2003). Although household preferences are not the focus of this paper, owing to their limited quantitative implications for explaining the VAR responses, our results imply that, at least qualitatively, positive output comovement arises naturally by simultaneously changing the assumptions about factor markets and household preferences in BHK (2007).

${ }^{7}$ See numerical results in Katayama and Kim (2015).
} 
our model. If factors are homogeneous, both sectors require extremely strong information stickiness to explain output comovement and hump-shaped responses in sectoral inflation and output. Furthermore, with firm-specific factors, firms' pricing decisions within the same sector are strategic complements (Woodford 2003). This has the effect of reducing the size of optimal price adjustments, which further dampens the sectoral price responses, especially in periods immediately after the shock. Through these mechanisms, the effect of monetary policy shocks is amplified and is manifested in the form of hump-shaped impulse responses in sectoral output and inflation.

Information rigidities have been studied in the literature to account for the realistic dynamics of aggregate variables (Mankiw and Reis 2002, 2006, Mackorwiak and Wiederholt 2009, Woodford 2001, Gorodnichenko 2008). Along with Mankiw et al. (2004) and Carroll (2003), Coibion and Gorodnichenko $(2012,2015)$ provide evidence that information rigidities are prevalent in various agents' decision-making processes. Our findings provide further support for information rigidities by demonstrating the capability of sticky information to account for the sectoral ouput and inflation dynamics following monetary policy shocks.

A number of papers in the literature have proposed different frictions to correct for the negative comovement in sectoral output. BHK $(2003,2007)$ propose sticky wages, borrowing constraints on households, and the input-output structure of production as promising ideas to address the problem. The effects of these frictions on the comovement of sectoral outputs have been studied in the following papers: Carlstrom and Fuerst (2010) examine the effects of sticky wages in conjunction with housing construction adjustment costs and consumption habit persistence; Monacelli (2009) and Sterk (2010) investigate the credit frictions channel; Sudo (2012) studies input-ouput linkages; and Bouakez et al. (2011) examine the interactions between input-output linkages and limited labour mobility. Although these frictions lead to positive output comovement between durable and nondurable goods, none of them can explain the delayed and hump-shaped responses in sectoral inflation as observed in the empirical evidence.

The paper proceeds as follows. Section 2 shows empirical impulse responses in sectoral output and inflation. Section 3 explains the role of heterogeneous production factors. Section 4 explains the mechanism of the sticky-information model with firm-specific factors. Section 5 evaluates the sticky-information model from an empirical perspective and Section 6 concludes.

\section{Empirical Evidence}

In this section, we present empirical impulse responses of sectoral output and inflation to a monetary policy shock using a VAR. We estimate a 9-variable VAR with 4 lags on the U.S. data (1970Q1-2007Q4). The included variables are real consumption of durable goods, real residential investment, real consumption of NDSV, the price indices of these variables, a commodity price in- 
dex, the federal funds rate and the growth rate of the monetary aggregate. ${ }^{8}$ We took the logarithm of each variable except for the federal funds rate and the growth rate of monetary aggregate. We follow the methodology used by Erceg and Levin $(2005,2006)$ and Christiano et al. (2005) to identify the responses of the above variables to a federal funds rate shock. That is, with the ordering of the variables mentioned above, we assume that the variables listed before the federal funds rate do not respond contemporaneously to a shock in the federal funds rate. As discussed in Section 5, we include the growth of the monetary aggregate to infer the short-run interest semi-elasticity of money. What makes our analysis different from Erceg and Levine's $(2005,2006)$ is that we use NDSV instead of real GDP excluding residential investment and durable goods. In addition, we show sectoral inflation responses that are not reported in their paper.

Figure 1 shows the responses of durable goods, residential investment, NDSV and the inflation rate in each sector to an unexpected fall in the federal funds rate. The figure reveals some salient features of sectoral inflation and output dynamics. First, the pace and magnitude of price adjustments differ across sectors. Despite these differences, however, all the quantities increase following a monetary easing. Second, durable goods and residential investment are more interest rate sensitive than NDSV. Peak responses of durable goods and residential investment are approximately 5 and 11 times larger than that of NDSV, respectively. Third, output and inflation in each sector respond to the shock with delays and exhibit hump-shaped responses.

This evidence confirms that the negative comovement result in BHK (2007) is at odds with the data. Moreover, the effects of monetary policy shocks propagate through disaggregated levels with inertia and persistence. In the following analyses, we explore ways to explain these empirical comovement patterns at the sectoral level.

\section{The Model with Heterogeneous Factors}

In this section, we assume that production factors are heterogeneous in the BHK model. ${ }^{9}$ BHK (2007) argue that the negative output comovement is robust to factor market heterogeneity. In particular, they show that factor market heterogeneity can at best make the output of durable goods acyclical to a monetary policy shock if these goods are flexibly priced. We show that allowing for heterogeneity in all factors of production can generate positive output comovement through interactions with other mechanisms in the model such as sticky prices and complementarity of goods.

\footnotetext{
${ }^{8}$ See the Data Appendix for details.

${ }^{9}$ Sticky information will be introduced in the next section.
} 


\subsection{The Model with Firm-Specific Factors}

Following Woodford (2003), we assume that labour and capital are both firm specific. In other words, each intermediate goods producer owns a fixed level of capital stock and employs workers whose skills are specific to the individual firm. In essence, our model is similar to the yeoman farmer model of Ball and Romer (1990), in which each household engages in the production of consumption goods using its own workforce. Here, we assume instead that the representative household owns all types of firm-specific labour and diversifies away idiosyncratic risks arising from nominal rigidities.

Nondurable goods and durable goods are produced by industries indexed by $j=c$ and $x$, respectively, and each industry consists of a continuum of intermediate goods producers indexed by $z \in$ $[0,1]$. As in BHK (2007), the representative household chooses nondurable consumption, $C_{t}$, the stock of durable goods, $D_{t}$, investment in new durable goods, $X_{t}$, and one-period nominal bonds, $S_{t}$. In addition, the representative household determines hours worked, $N_{j, t}(z)$, for each type of worker employed by a particular intermediate goods producer. In this set-up, the representative household's problem is to maximize the following lifetime utility,

$$
\mathbb{E}_{t}\left[\sum_{i=0}^{\infty} \beta^{i}\left\{u\left(C_{t+i}, D_{t+i}\right)-\int_{0}^{1} v\left(N_{c, t+i}(z)\right) d z-\int_{0}^{1} v\left(N_{x, t+i}(z)\right) d z\right\}\right]
$$

subject to

$$
\begin{aligned}
P_{c, t} C_{t}+P_{x, t} X_{t}+M_{t} \leq \sum_{j=C, X} \int_{0}^{1} W_{j, t}(z) N_{j, t}(z) d z+\Pi_{t} & +T_{t} \\
& +\left(1+i_{t-1}\right) S_{t-1}-S_{t}+M_{t-1},
\end{aligned}
$$

and

$$
D_{t}=X_{t}+D_{t-1}(1-\delta)
$$

where $P_{c, t}$ and $P_{x, t}$ are the nominal prices of nondurable and durable goods, $M_{t}$ is the nominal money balance carried over to period $t, W_{j, t}(z)(j=c, x)$ is the nominal wage for type $(j, z)$ labour, $\Pi_{t}$ is the dividend from firms, $T_{t}$ is the nominal lump-sum transfer from the government, $i_{t}$ is the nominal interest rate, $\beta$ is the subjective discount factor, $\delta$ is the depreciation rate of durable goods, and $\mathbb{E}_{t}$ is an expectations operator conditional on information available at period $t$.

Let $M U_{t}^{C} \equiv \partial u\left(C_{t}, D_{t}\right) / \partial C_{t}, M U_{t}^{D} \equiv \partial u\left(C_{t}, D_{t}\right) / \partial D_{t}$ and $\Gamma_{t}$ denote the marginal value of durable goods, or the Lagrange multiplier on equation (1). The first-order conditions for the 
household problem are

$$
\begin{aligned}
v^{\prime}\left(N_{j, t}(z)\right) & =\frac{W_{j, t}(z)}{P_{c, t}} M U_{t}^{c}=\frac{W_{j, t}(z)}{P_{x, t}} \Gamma_{t}, \\
M U_{t}^{C} \frac{P_{x, t}}{P_{c, t}} & =M U_{t}^{D}+\beta(1-\delta) E_{t}\left[M U_{t+1}^{C} \frac{P_{x, t+1}}{P_{c, t+1}}\right],
\end{aligned}
$$

and

$$
M U_{t}^{C}=\beta\left(1+i_{t}\right) E_{t} M U_{t+1}^{C} \frac{P_{c, t+1}}{P_{c, t}} .
$$

Equation (2) is a contemporaneous relationship that equates the marginal disutility of labour and the marginal utility of consuming $W_{j, t}(z) / P_{c, t}$ units of nondurable goods that can be purchased through additional wage income. The second equality in the same equation states that households equate the marginal value per dollar spent on durable and nondurable goods. Equation (3) states that consumers equate the opportunity cost of purchasing a unit of durable goods and the marginal utility of consuming durable goods plus the expected value of capital gains from holding durable goods until the beginning of next period. Finally, (4) is a standard consumption-savings Euler equation.

Following BHK (2007), money demand is equal to nominal GDP,

$$
M_{t}=P_{c, t} C_{t}+P_{x, t} X_{t}
$$

while the money supply is controlled by the monetary authority through a money-growth rule of the form

$$
\Delta m_{t}=\rho_{m} \Delta m_{t-1}+\varepsilon_{t}
$$

where $m_{t}$ is the logarithm of the nominal money balance, $\varepsilon_{t}$ is an i.i.d. mean-zero monetary policy shock and $\rho_{m}$ is the persistence of the money supply.

Real GDP is defined as

$$
Y_{t}=P_{c, s s} C_{t}+P_{x, s s} X_{t},
$$

where $P_{c, s s}$ and $P_{x, s s}$ are the steady-state values of nondurable and durable goods prices, respectively. The aggregate price level is given by the ratio of nominal GDP to real GDP.

Turning to the production side, final goods producers purchase intermediate goods in a competitive market and combine them into final goods through the Dixit-Stiglitz aggregator:

$$
X_{t}=\left[\int_{0}^{1} X_{t}(z)^{\frac{\varepsilon-1}{\varepsilon}} d z\right]^{\frac{\varepsilon}{\varepsilon-1}} \text { and } C_{t}=\left[\int_{0}^{1} C_{t}(z)^{\frac{\varepsilon-1}{\varepsilon}} d z\right]^{\frac{\varepsilon}{\varepsilon-1}}
$$

where $\varepsilon>1$ is the elasticity of demand for intermediate goods. From the optimality conditions of 
final goods firms, the prices of final goods are given by

$$
P_{j, t}=\left[\int_{0}^{1} P_{j, t}(z)^{1-\varepsilon} d z\right]^{\frac{1}{1-\varepsilon}}, \text { for } j=c, x
$$

where $P_{j, t}(z)$ is the price of an intermediate input indexed by $z \in[0,1]$ in sector $j=c, x{ }^{10}$ In this set-up, the demand for each intermediate good is given by

$$
X_{t}(z)=\left(\frac{P_{x, t}(z)}{P_{x, t}}\right)^{-\varepsilon} X_{t} \text { and } C_{t}(z)=\left(\frac{P_{c, t}(z)}{P_{c, t}}\right)^{-\varepsilon} C_{t} .
$$

A continuum of monopolistically competitive suppliers in two sectors produce intermediate goods subject to sticky prices. The probability that a firm is unable to adjust its price is denoted by $\theta_{j} \in(0,1)$. As in standard New Keynesian models, firms post new prices, whenever possible, taking into account the possibility that the price may be held fixed in the future with probability $\theta_{j}$. That is, firm $z$ in sector $j$ chooses the optimal price, $P_{j, t}^{*}(z)$, that maximizes

$$
\mathbb{E}_{t} \sum_{i=0}^{\infty}\left(\theta_{j} \beta\right)^{i} M U_{t+i}^{c}\left[\frac{P_{j, t}^{*}(z)}{P_{c, t+i}} Y_{j, t+i}(z)-\frac{W_{j, t+i}(z)}{P_{c, t+i}} N_{j, t+i}(z)\right]
$$

subject to equation (8) and the production technology

$$
Y_{j, t}(z)=F\left(K, N_{j, t}(z)\right)
$$

where $Y_{j, t}(z)$ is firm-level production, $K$ is the fixed capital held by firm $z$ in sector $j$, and $N_{j, t}(z)$ is the labour demanded by that firm. The optimal pricing condition is

$$
P_{j, t}^{*}(z)=\mu \frac{\sum_{i=0}^{\infty}\left(\theta_{j} \beta\right)^{i} \mathbb{E}_{t}\left[M U_{t+i}^{c} P_{j, t+i}^{\varepsilon} P_{c, t+i}^{-1} Y_{j, t+i} M C_{j, t+i}(z)\right]}{\sum_{i=0}^{\infty}\left(\theta_{j} \beta\right)^{i} \mathbb{E}_{t}\left[M U_{t+i}^{c} P_{j, t+i}^{\varepsilon} P_{c, t+i}^{-1} Y_{j, t+i}\right]} \text { for } j=c, x,
$$

where $\mu \equiv \frac{\varepsilon}{\varepsilon-1}$ is the desired markup,

$$
Y_{j, t} \equiv\left\{\begin{array}{c}
C_{t} \text { if } j=c \\
X_{t} \text { if } j=x
\end{array}\right.
$$

and

$$
M C_{j, t}(z)=\frac{W_{j, t}(z)}{\frac{d F}{d N}\left(N_{j, t}(z), K\right)}
$$

is the marginal cost of production. Note that marginal cost is heterogeneous across sectors and

\footnotetext{
${ }^{10}$ Sectors " $c$ " and " $x$ " represent the nondurable goods sector and the durable goods sector, respectively.
} 
firms, owing to heterogeneous factors. ${ }^{11}$ If the production factors are homogeneous, the marginal cost is the same across two sectors and all firms:

$$
M C_{t}=\frac{W_{t}}{\frac{\partial F}{\partial N}(K, N)} .
$$

\subsection{The Effect of Production-Factor Heterogeneity}

The assumption of heterogeneous factors breaks the tight link between marginal costs across sectors as shown by equations (11) and (12). To illustrate how this difference affects output comovement, we solve the model numerically by log-linearizing the equilibrium conditions around the steady state. ${ }^{12}$ For comparison, we use the same functional forms and parameter values as in BHK (2007). ${ }^{13}$ That is, the production function is $Y=A K^{\alpha} N^{1-\alpha}$, and household preferences are represented by the CES utility function,

$$
u(C, D)=\frac{\sigma}{\sigma-1}\left[\left\{\psi_{c} C^{\frac{\rho-1}{\rho}}+\left(1-\psi_{c}\right) D^{\frac{\rho-1}{\rho}}\right\}^{\frac{\rho}{\rho-1}}\right]^{\frac{\sigma-1}{\sigma}}
$$

with $\sigma=\rho=1 .{ }^{14}$ Figure 2 plots impulse responses following an unexpected i.i.d. monetary expasion for various combinations of price stickiness under different assumptions about factor markets. The figure indicates that any positive combination of price stickiness generates positive output comovement if factors are heterogeneous. This is in contrast to the responses under homogeneous factors.

To understand this, consider a log-linearized version of the pricing equation for flexibly priced durable goods producers: ${ }^{15}$

$$
p_{x, t}^{*}-p_{x, t}=\frac{1}{1+\varepsilon \omega}\left(\omega x_{t}-\gamma_{t}\right),
$$

where $\omega=\left(\alpha+\eta^{-1}\right) /(1-\alpha)$ and

$$
\gamma_{t}=[1-\beta(1-\delta)] \sum_{i=0}^{\infty} \beta^{i}(1-\delta)^{i} \mathbb{E}_{t} m u_{d, t+i}
$$

As emphasized by BHK (2007), the marginal value of long-lived durable goods is almost invariant

\footnotetext{
${ }^{11}$ All firms that are allowed to adjust prices in sector $j$ choose the same optimal price because the marginal cost is a function of the firm's optimal price.

${ }^{12}$ Details of the log-linearized model are shown in the Technical Appendix.

${ }^{13}$ The parameter values are given in Table 1.

${ }^{14} \sigma$ and $\rho$ denote the intertemporal elasticity of substitution and the intratemporal elasticity of substitution between durable and nondurable goods, respectively.

${ }^{15}$ Variables in lower-case letters indicate percentage deviations from the steady state. Note that $\theta_{x}=0$ for flexibly priced goods.
} 
to shocks since the marginal utility of durable goods depends only on the stock of durable goods under their parameterization of household preferences. This implies that $\gamma \simeq 0$. Moreover, since all producers set the same price if prices are flexible, the sectoral price is equal to the optimal price: $p_{x, t}^{*}=p_{x, t}$. Then, equation (14) indicates that the output of durable goods does not change: $x=0$. Suppose, instead, that durable goods prices do not adjust immediately owing to sticky prices. Then, the sectoral average of durable goods prices is lower than the price posted by optimizing firms. This implies that the production of durable goods increases in much the same way as it does in a one-sector sticky-price model.

As argued by BHK (2007), the output of durable goods does not increase after monetary exansion if it is flexbly priced in the current set-up. But even in this case, factor heterogeneity can facilitate other mechanisms in the model to stimulate the demand for durable goods along with nondurable goods. For example, suppose that household preferences exhibit complementarity between durable and nondurable goods. That is, the intratemporal elasticity of substitution is less than one: $\rho<\sigma=1$. In this alternative set-up, the log-linearized marginal utility of durable goods is

$$
m u_{d, t}=\frac{\rho^{-1}-\sigma^{-1}}{1+\frac{1-\psi_{c}}{\psi_{c}}\left(\frac{D_{s s}}{C_{s s}}\right)^{1-\rho^{-1}}} c_{t}-\left(\frac{\rho^{-1}}{1+\frac{1-\psi_{c}}{\psi_{c}}\left(\frac{D_{s s}}{C_{s s}}\right)^{1-\rho^{-1}}}+\frac{\sigma^{-1}}{1+\left\{\frac{1-\psi_{c}}{\psi_{c}}\left(\frac{D_{s s}}{C_{s s}}\right)^{1-\rho^{-1}}\right\}^{-1}}\right) d_{t},
$$

where $D_{s s}$ and $C_{s s}$ are the steady-state consumption of durable and nondurable goods, respectively. Given that variations in the stock of durable goods are much smaller than variations in nondurable goods, the first term in equation (16) tends to dominate the second term. Moreover, given $\rho<\sigma$, this term is positive. It follows that the marginal value of durable goods in equation (15) increases with the cumulative increase in the consumption of nondurable goods, holding other things constant.

Although its quantitative implication is modest, Figure 3 indicates that a mild degree of complementarity between durable and nondurable goods could generate positive comovement between the two goods if factors are heterogeneous. ${ }^{16}$ This is in contrast to the result in BHK (2003) that a positive comovement between durable and nondurable goods requires an extremely large degree of complementarity between the two goods. ${ }^{17}$

The results in this section show that factor heterogeneity has a significant implication for the comovement of output. If factors are homogeneous, the relative price between the two types of goods

\footnotetext{
${ }^{16}$ For the elasticity of substitution between housing and nondurable goods, Flavin and Nakagawa (2008), Li et al. (forthcoming), and Bajari et al. (2013) report estimated values of 0.1, 0.5, and 0.8, respectively. For durable consumption goods, the estimates obtained by Yogo (2006) and Gomes et al. (2009) range between 0.5 and 0.8.

${ }^{17} \mathrm{BHK}$ (2003) show that $\rho$ needs to be as small as 0.01 to generate positive comovement with homogeneous factors.
} 
will change sharply owing to factor-price equalization and heterogeneous price stickiness across sectors. This, in turn, generates negative comovement between the two goods through a strong substitution effect. In contrast, by shutting down the factor-price equalization channel, positive comovement between durable and nondurable goods could arise naturally through price stickiness or complementarity between goods, for any combination of price stickiness across sectors.

\section{Sticky Information and Firm-Specific Factors}

In this section, we add sticky information to both goods in the model with firm-specific factors. We examine how their interactions amplify the effects of a monetary policy shock and lead to delayed responses in sectoral inflation and output.

\subsection{The Dual-Stickiness Model with Firm-Specific Factors}

As in the previous section, firms post new prices whenever possible, taking into account the possibility that the price may be held fixed in future periods with positive probabilities. In addition, as in Mankiw and Reis (2002), we assume that only a fraction of optimizing firms is allowed to update information while, others base their decisions on information updated in the past. Our two-sector dual-stickiness model builds on Dupor et al. (2010), in which both of these frictions exist in a one-sector model. Mathematically, a firm $z$ in sector $j$ with $k$-period-old information chooses the price, $P_{j, t, k}^{*}(z)$, to maximize

$$
\mathbb{E}_{t-k} \sum_{i=0}^{\infty}\left(\theta_{j} \beta\right)^{i} M U_{t+i}^{c}\left[\frac{P_{j, t, k}^{*}(z)}{P_{c, t+i}} Y_{j, t+i}(z)-\frac{W_{j, t+i}(z)}{P_{c, t+i}} N_{j, t+i}(z)\right]
$$

subject to equations (8) and (9). The optimal pricing condition is

$$
P_{j, t, k}^{*}(z)=\mu \frac{\sum_{i=0}^{\infty}\left(\theta_{j} \beta\right)^{i} \mathbb{E}_{t-k}\left[M U_{t+i}^{c} P_{j, t+i}^{\varepsilon} P_{c, t+i}^{-1} Y_{j, t+i} M C_{j, t+i}(z)\right]}{\sum_{i=0}^{\infty}\left(\theta_{j} \beta\right)^{i} \mathbb{E}_{t-k}\left[M U_{t+i}^{c} P_{j, t+i}^{\varepsilon} P_{c, t+i}^{-1} Y_{j, t+i}\right]} \text { for } j=c, x
$$

Equation (17) indicates that there is a distribution of optimal prices indexed by $k$ in each sector in a given period. ${ }^{18}$ However, the assumption that stickiness in price and information occurs independently makes the aggregation of optimal prices tractable. To be more specific, each firm in sector $j=c, x$ will be able to update information and prices with probability $1-\phi_{j}$ and $1-\theta_{j}$, respectively. This implies that, in every period, only a fraction $\left(1-\theta_{j}\right)\left(1-\phi_{j}\right)$ of firms in sector $j$ can adjust prices based on the latest information, while a fraction $\left(1-\theta_{j}\right) \phi_{j}$ of firms do so using

\footnotetext{
${ }^{18}$ As in the previous section, all firms facing the same information set in sector $j$ choose the same optimal price if they have an opportunity to update prices.
} 
vintage information. Notice that the fraction of re-optimizing firms with vintage $k$ information set in the total number of re-optimizing firms is $(1-\phi) \phi^{k}$. This implies that the optimal price index in sector $j$ in period $t$ can be written as

$$
Q_{j, t} \equiv\left[\left(1-\phi_{j}\right) \sum_{k=0}^{\infty} \phi_{j}^{k}\left(P_{j, t, k}^{*}\right)^{1-\varepsilon}\right]^{\frac{1}{1-\varepsilon}} \text { for } j=c, x
$$

Furthermore, the sectoral price index can be written as follows:

$$
P_{j, t}=\left[\theta_{j} P_{j, t-1}^{1-\varepsilon}+\left(1-\theta_{j}\right)\left(Q_{j, t}\right)^{1-\varepsilon}\right]^{\frac{1}{1-\varepsilon}} \text { for } j=c, x
$$

\subsection{Sticky Information, Positive Comovement and Delayed Responses}

By having sticky information with heterogeneous factors, we can show that positive comovement occurs. From the previous section, any strictly positive price stickiness in each sector generates positive comovement. Thus, it suffices to consider flexibly priced goods. For ease of exposition, consider flexibly priced durable goods. ${ }^{19}$ The sectoral price index for durable goods is obtained by log-linearizing equations (18) and (19):

$$
p_{x, t}=\left(1-\phi_{x}\right) \sum_{k=0}^{\infty} \phi_{x}^{k} p_{x, t, k}^{*}
$$

Equation (20) shows that the sectoral price of flexibly priced goods is the weighted average of optimal prices based on vintage information. This implies that the sectoral price does not immediately adjust to the optimal price based on full information. On the other hand, the log-linearized pricing equation for a full-information firm links the output of durable goods and their optimal price relative to the sectoral price:

$$
p_{x, 0, t}^{*}-p_{x, t}=\frac{1}{1+\epsilon \omega}\left(\omega x_{t}-\gamma_{t}\right)
$$

Given $\gamma_{t} \simeq 0$, the fact that the sectoral-price response lags behind the full-information optimal price implies that the output of durable goods increases after a monetary expansion. A similar argument holds for flexibly priced nondurable goods. Since this argument holds for any value of information stickiness, it follows that any combination of strictly positive information stickiness across sectors generates positive comovement between durable and nondurable goods.

Firm-specificity of production factors has a further implication for the inflation and output dynamics generated by sticky information and sticky prices. It makes the intensive margin of price

\footnotetext{
${ }^{19}$ We assume that $\sigma=\rho=1$ to isolate the effect of sticky information.
} 
adjustments smaller, which is captured by the price elasticity with respect to the marginal cost in equation (21). The elasticity diminishes by a factor of $1+\varepsilon \omega$ relative to the case where factors are homogeneous. ${ }^{20}$ As in Woodford (2003), this is due to strategic complementarity in price setting in monopolistic competition. That is, the extent to which a firm adjusts its price depends on whether competitors in the same industry are likely to change prices simultaneously. Here, the fact that the marginal cost differs across firms makes the optimal size of the price adjustment smaller. As a result, the size of the sectoral price adjustment is less pronounced, while that of the sectoral output response is greater with firm-specific factors than otherwise.

In conjunction with firm-specific factors, sticky information can generate hump-shaped responses in sectoral inflation, even for flexibly priced durable goods. Recall, from Section 2, that the inflation of residential investment exhibits a hump-shaped pattern, while the price of housing may be viewed as flexible since housing prices are negotiable (BHK 2007). The model with sticky information can explain this empirical observation. This is an important feature that distinguishes sticky information from sticky prices. Whereas sticky information allows firms to adjust prices gradually over time in response to a shock, sticky prices induce firms to front-load the effects of potentially having to maintain the same price in the future.

Note that a backward indexation rule is often assumed in the literature as a mechanical device to generate a hump-shaped inflation response in the presence of sticky prices. ${ }^{21}$ This rule generates backward-looking inflation dynamics through indexing non-optimized prices to past inflation. However, this has the undesirable feature that non-optimizing firms change prices through an indexation rule every period, which is inconsistent with the micro evidence that some prices are held fixed for certain periods. Moreover, the backward indexation rule is unable to generate a hump-shaped inflation response in a flexible-price environment, because this mechanism works only when a sufficient fraction of firms are bound by sticky prices. In contrast, with sticky information, sticky prices remain sticky and an inflation response is delayed for a flexibly priced good. This implies that sticky information provides a better explanation for the sluggish responses of inflation than the ad hoc assumption of indexation to past inflation.

To see these results numerically, Figure 4 shows simulated responses to an unexpected and persistent increase in money growth. ${ }^{22}$ For convenience, the figure shows the case in which nondurable goods prices are sticky and durable goods prices are flexible, ${ }^{23}$ while the degree of information stickiness is identical in the two sectors. ${ }^{24}$ The figure shows that the production of durable

\footnotetext{
${ }^{20}$ The optimal pricing equation for homogeneous factors is $p_{x, 0, t}^{*}-p_{x, t}=\omega y_{t}-\gamma_{t}$.

${ }^{21}$ For example, see Christiano et al. 2005.

${ }^{22}$ The persistence of money growth captures a more realistic evolution of monetary policy and allows us to make a comparison with the VAR responses later on.

${ }^{23}$ This combination of price stickiness generates the most severe negative comovement in BHK (2007). We set $\theta_{c}=0.5$ and $\theta_{x}=0$.

${ }^{24} \mathrm{We}$ allow for asymmetric information stickiness across sectors in the next section.
} 
goods increases for any degree of positive sticky information, while the output of nondurable goods always increases since firms in this sector are subject to both sticky prices and sticky information. Moreover, as the degree of information stickiness increases, sectoral price adjustments are dampened at the beginning and accelerate later on. This "S-shaped" response of sectoral prices is due to the effects of sticky information and the firm-specificity of production factors, as we described above. This leads to hump-shaped responses in sectoral inflation and output, which is in line with the VAR responses in Section 2.

\section{Accounting for Sectoral Responses to a Monetary Shock}

In this section, we examine to what extent our two-sector model featuring sticky information and firm-specific factors can explain the VAR impulse responses shown in Figure 1. In doing so, we compare both model-implied and VAR responses for the following variables: residential investment, NDSV, and the inflation rates for these two variables. Following BHK (2007), we regard the price of residential investment as being flexible $\left(\theta_{x}=0\right)$, given that housing prices are negotiable. We estimate the degree of sticky information in each sector by the minimum-distance estimation method following Christiano et al. (2005). Namely, we find the values $\phi_{c}$ and $\phi_{x}$ that minimize the weighted sum of the squared distance between the model and empirical impulse-response functions for 24 quarters, excluding the initial period in which responses are constrained to be zero in the VAR analysis. Parameters that are fixed before estimation are shown in Table 1. Most of the parameter values are taken from BHK (2007), but there are a few others that are not. In particular, we set the intratemporal elasticity of substitution, $\rho$, to 0.8 following Bajari et al. (2013). The price-stickiness parameter for nondurable goods, $\theta_{c}$, is set to 0.5 following Bils and Klenow (2004). The persistence of the money-growth rule, $\rho_{M}$, is estimated from the monetary aggregate series using the AR1 specification.

To make a meaningful comparison between model-implied and VAR impulse responses, we implement the minimum-distance estimation as follows. First, we estimate the short-run interest semi-elasticity of money from an implied contemporaneous relationship between the federal funds rate and money growth. This is done by measuring the initial response of money growth to an identified federal funds rate shock in the VAR analysis. This information determines the size of the initial monetary shock that feeds into the simulation of our model. Our estimation result in Section 2 shows that a one-standard-deviation (annualized 0.6-percentage-point) decline in the federal funds rate translates into an approximately 0.3-percentage-point increase in money growth. Christiano et al. $(1999,2005)$ report that estimates of elasticity with respect to an annualized federal funds rate range between -0.1 and -1 percent. In our case, it is roughly -0.5 percent.

Second, as in Christiano et al. (2005) and Rotemberg and Woodford (1997), we adjust the 
timing of our model presented in Section 4 to make the model-implied responses comparable to those of the VAR. This adjustment ensures that impulse responses generated by our model are zero in the initial period when a monetary shock occurs. In doing so, we assume that housholds and firms must make their decisions one period in advance. In addition, the nominal aggregate demand is equal to the nominal money balance in the previous period. Details of these adjustments are explained in the Technical Appendix.

As shown in Table 2, the point estimates of $\phi_{c}$ and $\phi_{x}$ are 0.49 and 0.74 with standard deviations of 0.15 and 0.05 , respectively. These values imply that, on average, producers update information every 5 to 6 months for NDSV and every 11 to 12 months for residential investment. Our result shows that the degree of information stickiness is higher for residential investment than for NDSV. Interestingly, Coibion and Gorodnichenko (2015) find that information rigidities, estimated from the Survey of Professional Forecasters, differ across macroeconomic variables. In particular, information rigidities associated with residential investment and housing starts are larger than those associated with other variables. Our estimates are consistent with their findings in the sense that our point estimates indicate a greater degree of information stickiness for residential investment than for NDSV. ${ }^{25}$

Figure 5 shows the model-implied and empirical impulse responses to a monetary shock. Solid lines indicate responses generated by our model. Dashed lines are point estimates of VAR impulseresponse functions. The regions inside the dotted lines correspond to 95 percent confidence intervals around the point estimates. The figure reveals that the model-implied impulse responses capture the overall dynamics of the four variables reasonably well, although the model has difficulties explaining the declines in residential investment following the initial sharp increases.

To illustrate the role of firm-specific production factors, Figure 5 also displays the case of homogeneous production factors. We re-estimate sticky information parameters for this case to give the model the best chance to match the data. A striking difference appears in the estimated information stickiness. The re-estimated $\phi_{c}$ and $\phi_{x}$ are now 0.91 and 0.91 with standard deviations of 0.02 and 0.01 , respectively. Information stickiness is similar in both sectors and their values are significantly larger than in the case of firm-specific factors. These values are unrealistically large given that implied average durations of information stickiness are 37 to 38 months for both NDSV and residential investment. Despite the significant increase in information stickiness, impulse responses in sectoral inflation peak much earlier than in the benchmark. Thus, production-factor

\footnotetext{
${ }^{25}$ One explanation for the observed heterogeneity of information rigidity across variables is that professional forecasters allocate different intensities of attention across variables as the rational inattention theory predicts. The result from our model implies that sectoral differences in the costs of information updating may also provide an alternative and complementary explanation for the observed heterogeneity of information rigidity across variables to the extent that professional forecastors infer suppliers' views about future developments in their businesses in shaping their predictions.
} 
heterogeneity plays a critical role in explaining the inflation dynamics with reasonable degrees of information rigidities.

\subsection{Interest-Rate Rule}

So far, we assumed that monetary policy follows a money-growth rule as in BHK (2007). An alternative characterization of monetary policy is to assume that the monetary authority controls the short-term interest rate through a feedback rule. We repeat the same exerise as above by replacing equation (6) with the following interest-rate rule considered in Coibion et al. (2012):

$$
i_{t}=\rho_{i, 1} i_{t-1}+\rho_{i, 2} i_{t-2}+\left(1-\rho_{i, 1}-\rho_{i, 2}\right)\left(\rho_{\pi} \pi_{t}+\rho_{x} x_{t}+\rho_{g y} \Delta y_{t}\right)+\varepsilon_{t}^{i},
$$

where $x_{t}$ is the output gap and $\varepsilon_{t}^{i}$ is an interest-rate shock. Following Coibion et al. (2012), we set $\rho_{i, 1}=1.05, \rho_{i, 2}=-0.13, \rho_{\pi}=2.5, \rho_{x}=0.11$, and $\rho_{g y}=1.5$. In addition, we consider a cashless economy in which equation (5) becomes redundant. In this set-up, changes in the nominal interest rate have a direct impact on the household's decision on the consumption of durable and nondurable goods through equation (4). This alternative specification of monetary policy does not affect our findings regarding the comovement between the output of durables and nondurables in Sections 3 and 4. However, because the intertemporal substitution of spending becomes highly sensitive to changes in the nominal interest rate, extra frictions are required to smooth out the expenditures on durable and nondurable goods. For this reason, we assume that the households' decisions are subject to consumption habits and the adjustment cost of durable goods as in Katayama and Kim (2015). More specifically, the utility of consumption becomes $u\left(C_{t}-\varrho_{c} C_{t-1}, D_{t}\right)$ and the law of motion for durable goods includes the adjustment-cost term as follows:

$$
D_{t}=(1-\delta) D_{t-1}+\left[1-h\left(\frac{X_{t}}{X_{t-1}}\right)\right] X_{t}
$$

where $h(\cdot)$ satisfies $h(1)=h^{\prime}(1)=0$ and $h^{\prime \prime}(1)=\psi_{h}>0$. We estimate the values of $\varrho_{c}$ and $\psi_{h}$ jointly with $\phi_{c}$ and $\phi_{x}$ by the minimum-distance estimation method.

As shown in Table 2, the point estimates of $\phi_{c}, \phi_{x}, \psi_{h}$ and $\varrho_{c}$ are 0.52, 0.78, 2.1 and 0.75 with standard deviations of $0.14,0.05,0.75$ and 0.04 , respectively. The estimated sticky-information parameters are close to the values estimated under the money-growth rule. The estimate for consumption habits is close to the value reported in Smets and Wouters (2007), while the estimate for the curvature of the adjustment-cost function is similar to the value in Christiano et al. (2005), in which the same function is applied to explain the adjustment cost of physical capital. Figure 6 shows impulse responses to a one-standard-deviation decrease in the nominal interest rate. The figure indicates that the properties of model-implied responses are similar to the case of the 
money-growth rule.

Even though we have consumption habit formation and the adjustment cost of residential investment, sticky information continues to play a critical role in generating hump-shaped responses in sectoral inflation. To show this, Figure 7 plots a simulation in which increases in the demand for both goods are driven by sticky prices instead of sticky information $\left(\theta_{c}=\theta_{x}=0.5, \phi_{c}=\phi_{x}=0\right)$. While the quantities are smoothed by habit formation and the adjustment cost, hump-shaped patterns in sectoral inflation are missing. Figure 7 also shows responses when production factors are homogeneous across sectors. As before, we re-estimate the parameters and report their values in Table 2. While the parameters for habit formation in purchasing nondurable goods and the adjustment cost of durable goods are relatively insensitive, the degree of information stickiness in both sectors is extremely large. Moreover, the sectoral inflation responses peak much earlier than in Figure 6. These results confirm that our findings are robust to the specification of monetary policy.

In sum, the analyses in this section suggest that sticky information and firm-specific factors help explain how inflation and output in each sector respond to a monetary policy shock, regardless of whether monetary policy is modelled as a money-growth rule or an interest-rate rule.

\section{Conclusion}

In this paper, we show that a combination of heterogeneous production factors and sporadic updating of information by both durable and nondurable goods producers leads to a positive comovement of output in the two sectors-even when the prices of durable goods are completely flexible and the prices of nondurables are sticky. In the absence of these frictions, changes in the output of flexibly priced durable goods and that of sticky-priced nondurable goods offset each other. Moreover, our model is a good match for the empirical responses in sectoral output and inflation to a monetary policy shock. Thus, the frictions proposed in this paper provide a tractable method to account for sectoral inflation and output dynamics following a monetary policy shock in a two-sector economy in much the same way that Mankiw and Reis $(2002,2006)$ stress in a one-sector model. An important feature of our model is that it can replicate the hump-shaped responses of inflation in each sector without assuming backward indexation to past inflation. In contrast to backward indexation, information rigidity has valid empirical support and is able to generate hump-shaped inflation responses even when goods are flexibly priced. 


\section{References}

[1] Aoki, Kosuke. 2001. “Optimal Monetary Policy Responses to Relative-Price Changes.” Journal of Monetary Economics, 48(1): 55-80.

[2] Bajari, Patrick, Phoebe Chan, Dirk Krueger, and Daniel Miller. 2013. "A Dynamic Model of Housing Demand: Estimation and Policy Implications.” International Economic Review, 54(2): 409-42.

[3] Ball, Laurence, and David Romer. 1990. "Real Rigidities and the Non-Neutrality of Money." The Review of Economic Studies, 57(2): 183-203.

[4] Barsky, Robert, Christopher House, and Miles Kimball. 2003. "Do Flexible Durable Goods Prices Undermine Sticky Price Models?” National Bureau of Economic Research Working Paper 9832.

[5] Barsky, Robert, Christopher House, and Miles Kimball. 2007. "Sticky Price Models and Durable Goods.” American Economic Review, 97(3): 984-98.

[6] Bils, Mark, and Peter J. Klenow. 2004. "Some Evidence on the Importance of Sticky Prices." Journal of Political Economy, 112(5): 947-85.

[7] Bouakez, Hafedh, Emanuela Cardia, and Francisco J. Ruge-Murcia. 2011. "Durable Goods, Inter-Sectoral Linkages and Monetary Policy." Journal of Economic Dynamics and Control, 35: $730-45$.

[8] Carlstrom, Charles, and Timothy Fuerst. 2010. "Nominal Rigidities, Residential Investment, and Adjustment Costs." Macroeconomic Dynamics, 14: 136-48.

[9] Carroll, Christopher. 2003. "Macroeconomic Expectations of Households and Professional Forecasters." Quarterly Journal of Economics, 118(1): 269-298.

[10] Christiano, Lawrence, Martin Eichenbaum, and Charles Evans. 1999. "Monetary Policy Shocks: What Have We Learned and To What End?" In Handbook of Macroeconomics, ed. J.B. Taylor and M. Woodford, volume 1A, 65-148. Amsterdam, The Netherlands: Elsevier Science B.V.

[11] Christiano, Lawrence, Martin Eichenbaum, and Charles Evans. 2005. "Nominal Rigidities and the Dynamic Effects of a Shock to Monetary Policy." Journal of Political Economy, 113(1): 1-45. 
[12] Coibion, Olivier, and Yuriy Gorodnichenko. 2012. "What Can Survey Forecasts Tell Us about Information Rigidities?" Journal of Political Economy, 120(1): 116-59.

[13] Coibion, Olivier, and Yuriy Gorodnichenko. 2015. "Information Rigidity and the Expectations Formation Process: A Simple Framework and New Facts.” American Economic Review, 105(8): 2644-78.

[14] Coibion, Olivier, Yuriy Gorodnichenko, and Johannes Wieland. 2012. "The Optimal Inflation Rate in New Keynesian Models: Should Central Banks Raise Their Inflation Targets in Light of the Zero Lower Bound?" Review of Economic Studies, 79: 1371-406.

[15] Dupor, Bill, Tomiyuki Kitamura, and Takayuki Tsuruga. 2010. "Integrating Sticky Prices and Sticky Information." The Review of Economics and Statistics, 92: 657-669.

[16] Erceg, Christopher, and Andrew Levin. 2005. "Optimal Monetary Policy with Durable Consumption Goods.” Board of Governors of the Federal Reserve System International Finance Discussion Papers, 748.

[17] Erceg, Christopher, and Andrew Levin. 2006. "Optimal Monetary Policy with Durable Consumption Goods.” Journal of Monetary Economics, 53(7): 1341-59.

[18] Flavin, Marjorie, and Shinobu Nakagawa. 2008. "A Model of Housing in the Presence of Adjustment Costs: A Structural Interpretation of Habit Persistence." American Economic Review, 98(1): 474-95.

[19] Gomes, João F., Leonid Kogan, and Motohiro Yogo. 2009. "Durability of Output and Expected Stock Returns.” Journal of Political Economy, 117(5): 941-86.

[20] Gorodnichenko, Yuriy. 2008. "Endogenous Information, Menu Costs and Inflation Persistence.” NBER Working Paper No. 14184.

[21] Jacobson, Louis S., Robert J. Lalonde, and Daniel G. Sullivan. 1993. "Endogenous Earnings Losses of Displaced Workers." American Economic Review, 83(4): 685-709.

[22] Katayama, Munechika and Kwang Hwan Kim. 2015. "The Delayed Effects of Monetary Shocks in a Two-sector New Keynesian Model.” Journal of Macroeconomics, 38: 243-59.

[23] Li, Wenli, Haiyong Liu, Fang Yang, and Rui Yao. forthcoming. "Housing Over Time and Over the Life Cycle: A Structural Estimation.” International Economic Review.

[24] Mackorwiak, Bartosz, and Mirko Wiederholt. 2009. "Optimal Sticky Prices under Rational Inattention." American Economic Review, 99(3): 769-803. 
[25] Mankiw, N. Gregory, and Ricardo Reis. 2002. "Sticky Information versus Sticky Prices: A Proposal to Replace the New Keynesian Phillips Curve." Quarterly Journal of Economics, 117(4): 1295-1328.

[26] Mankiw, N. Gregory, and Ricardo Reis. 2006. "Pervasive Stickiness." American Economic Review, 96(2): 164-9.

[27] Mankiw, N. Gregory, Ricardo Reis, and Justin Wolfers. 2004. "Disagreement About Inflation Expectations." In NBER Macroeconomics Annual 2003, Vol. 18, edited by Mark Gertler and Kenneth Rogoff, 209-48. Cambridge, MA: MIT Press.

[28] Meyer-Gohde, Alexander. 2009. "Linear Rational Expectations Models with Lagged Expectations: A Synthetic Method.” Mimeo.

[29] Monacelli, Tommasso. 2009. "New Keynesian Models, Durable Goods, and Collateral Constraints.” Journal of Monetary Economics, 56: 242-54.

[30] Reis, Ricardo. 2006a. "Inattentive Producers.” Review of Economic Studies, 73(3): 793-821.

[31] Reis, Ricardo. 2006b. "Inattentive Consumers." Journal of Monetary Economics. 53(8): 1761-1800.

[32] Rotemberg, Julio, and Michael Woodford. 1997. "An Optimization-Based Econometric Framework for the Evaluation of Monetary Policy.” NBER Macroeconomics Annual, 12: 297-346.

[33] Smets, Frank, and Rafael Wouters. 2007. "Shocks and Frictions in US Business Cycles: A Bayesian DSGE Approach.” American Economic Review, 97(3): 586-606.

[34] Sterk, Vincent. 2010. "Credit Frictions and the Comovement between Durable and NonDurable Consumption.” Journal of Monetary Economics, 57: 217-25.

[35] Sudo, Nao. 2012. "Sectoral Co-Movement, Monetary-Policy Shock, and Input-Output Structure." Journal of Money, Credit and Banking, 44(6): 1225-44.

[36] Wang, Pengfei, and Yien Wei. 2006. "Solving Linear Difference Systems with Lagged Expectations by a Method of Undetermined Coefficients." Federal Reserve Bank of St. Louis Working Paper 2006-003.

[37] Whelan, Karl. 2002. "A Guide to U.S. Chain Aggregated NIPA Data." The Review of Income and Wealth, 48(2): 217-33. 
[38] Woodford, Michael. 2001. "Imperfect Common Knowledge and the Effects of Monetary Policy. In Knowledge, Information, and Expectations in Modern Macroeconomics: In Honor of Edmund S. Phelps, edited by Philippe Aghion, Roman Frydman, Joseph Stiglitz, and Michael Woodford, 25-58. Princeton, NJ: Princeton University Press.

[39] Woodford, Michael. 2003. Interest and Prices: Foundations of a Theory of Monetary Policy. Princeton, NJ: Princeton University Press.

[40] Yogo, Motohiro. 2006. "A Consumption-Based Explanation of Expected Stock Returns." Journal of Finance, 61(2): 539-80.

[41] Zbaracki, Mark J., Mark Ritson, Daniel Levy, Shantanu Dutta, and Mark Bergen. 2004. "Managerial and Customer Costs of Price Adjustment: Direct Evidence from Industrial Markets." The Review of Economics and Statistics, 86(2): 514-33. 


\section{Tables}

\begin{tabular}{lll}
\hline \hline Parameter & Definition & Value \\
\hline$\theta_{c}$ & price stickiness for nondurables & 0.5 \\
$\theta_{x}$ & price stickiness for durables & 0 \\
$\alpha$ & capital share & 0.35 \\
$\beta$ & discount factor & 0.995 \\
$\eta$ & Frisch elasticity of labour supply & 1 \\
$\varepsilon$ & elasticity of demand for intermediate goods & 11 \\
$\delta$ & depreciation rate of durable stock & 0.0125 \\
$\rho_{m}$ & persistence of money growth & 0.53 in Fig. 4-7, and 0 elsewhere \\
$\sigma$ & intertemporal elasticity of substitution & 1 \\
$\rho$ & intratemporal elasticity of substitution & 0.8 in Fig. 5-7, $\leq 1$ in Fig. 3 \\
& & and 1 elsewhere \\
\hline \hline
\end{tabular}

Table 1: Structural parameters and values for simulation

Notes: The value of $\theta_{c}$ is based on Bils and Klenow (2004). The intratemporal elasticity of substitution is based on Bajari et al. (2013). The persistence of money growth is estimated from the MZM series (1970Q1-2007Q4), while the sticky-information parameter is estimated by the minimum-distance estimation method. The remaining values in the table are identical to BHK (2007).

\begin{tabular}{ccccc}
\hline \hline & \multicolumn{2}{c}{ Money-growth rule } & \multicolumn{2}{c}{ Interest-rate rule } \\
& Firm-specific factors & Homogeneous factors & Firm-specific factors & Homogeneous factors \\
\hline$\phi_{c}$ & 0.49 & 0.91 & 0.52 & 0.93 \\
& $(0.15)$ & $(0.02)$ & $(0.14)$ & $(0.02)$ \\
$\phi_{x}$ & 0.74 & 0.91 & 0.78 & 0.94 \\
& $(0.05)$ & $(0.01)$ & $(0.05)$ & $(0.01)$ \\
$\psi_{h}$ & - & - & 2.1 & 2.0 \\
& & & $(0.74)$ & $(0.77)$ \\
$\varrho_{c}$ & - & - & 0.75 & 0.75 \\
& & & $(0.04)$ & $(0.05)$ \\
\hline \hline
\end{tabular}

Table 2: Parameter estimates

Note: Numbers in parentheses indicate standard deviations. 


\section{Figures}
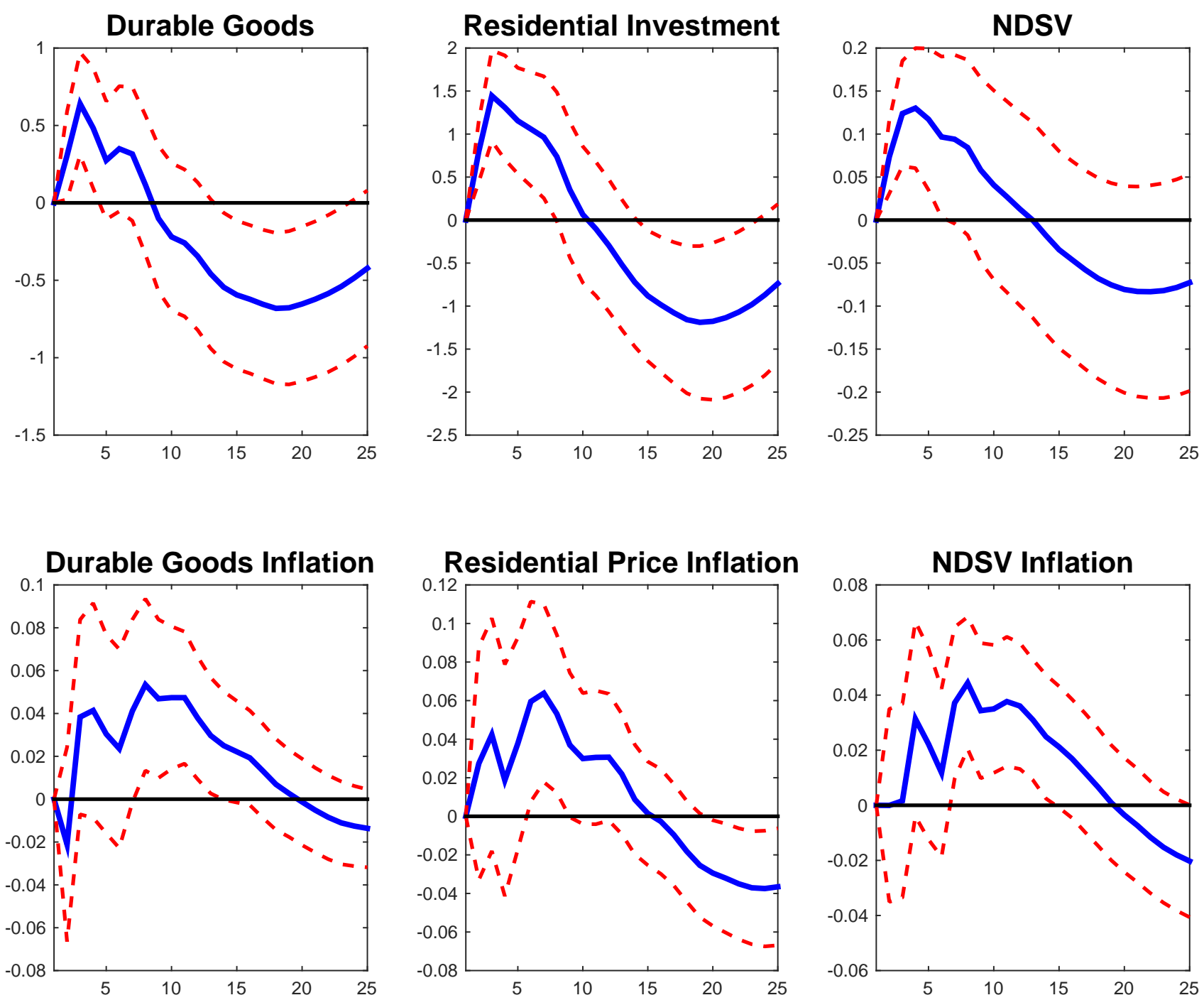

Figure 1: VAR impulse responses to a federal funds rate shock

Notes: The figure shows VAR responses of sectoral output and sectoral price inflation to a onestandard-deviation decrease in the federal funds rate. The units for the variables are percentages for the output series and percentage points for the inflation series. Dashed lines in the figure are 95 percent confidence intervals. See the Data Appendix for the sources and treatment of data. NDSV stands for nondurable goods and services. 
(a) Homogeneous factor markets
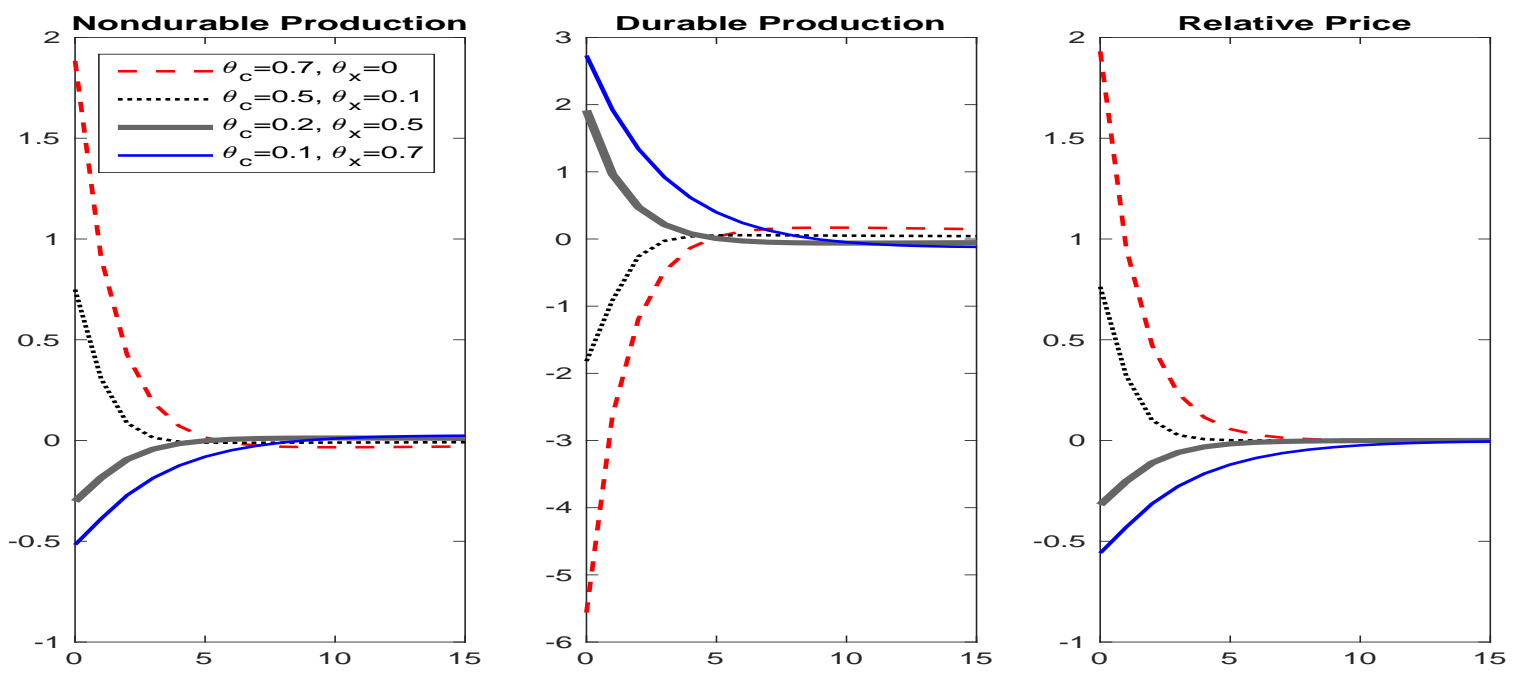

(b) Heterogeneous factor markets
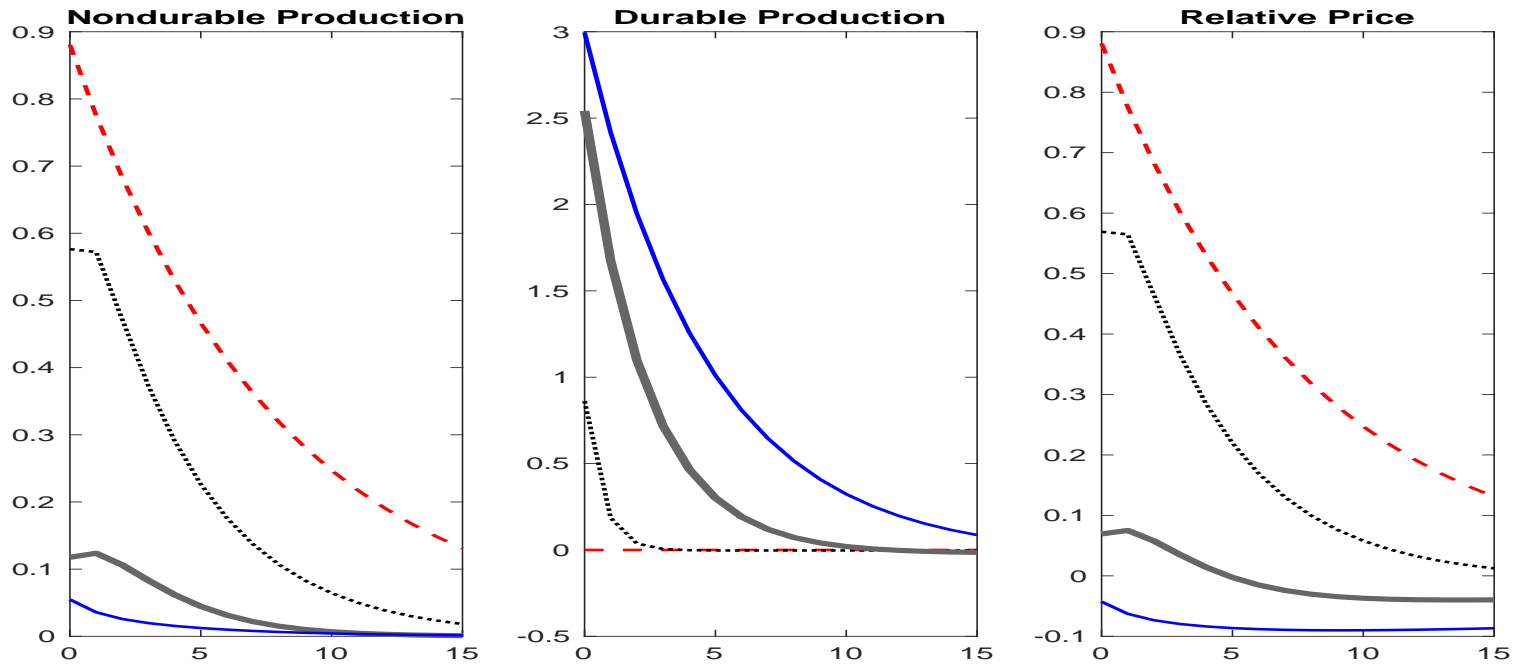

Figure 2: Model impulse responses following an i.i.d. money-growth shock

Notes: The figure shows impulse responses to a one-percentage-point temporary increase in money growth. The units are percentage deviations from the steady state. 

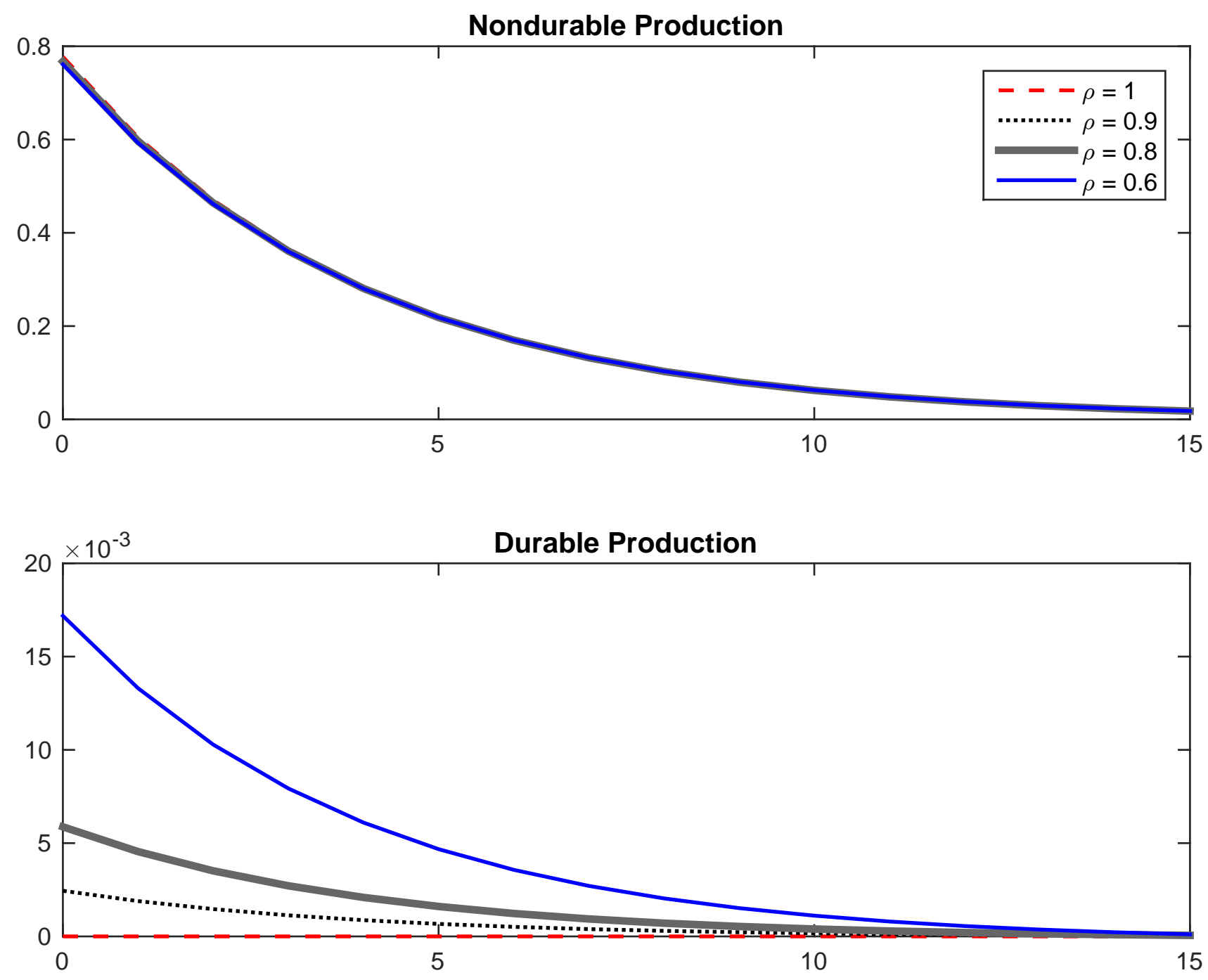

Figure 3: The effects of complementarity between durable and nondurable goods when factors are firm-specific

Notes: The figure shows impulse responses to a one-percentage-point temporary increase in money growth. The degree of price stickiness is $\theta_{c}=0.5$ and $\theta_{x}=0$. The intertemporal elasticity of substitution is set to 1 . The units are percentage deviations from the steady state. 

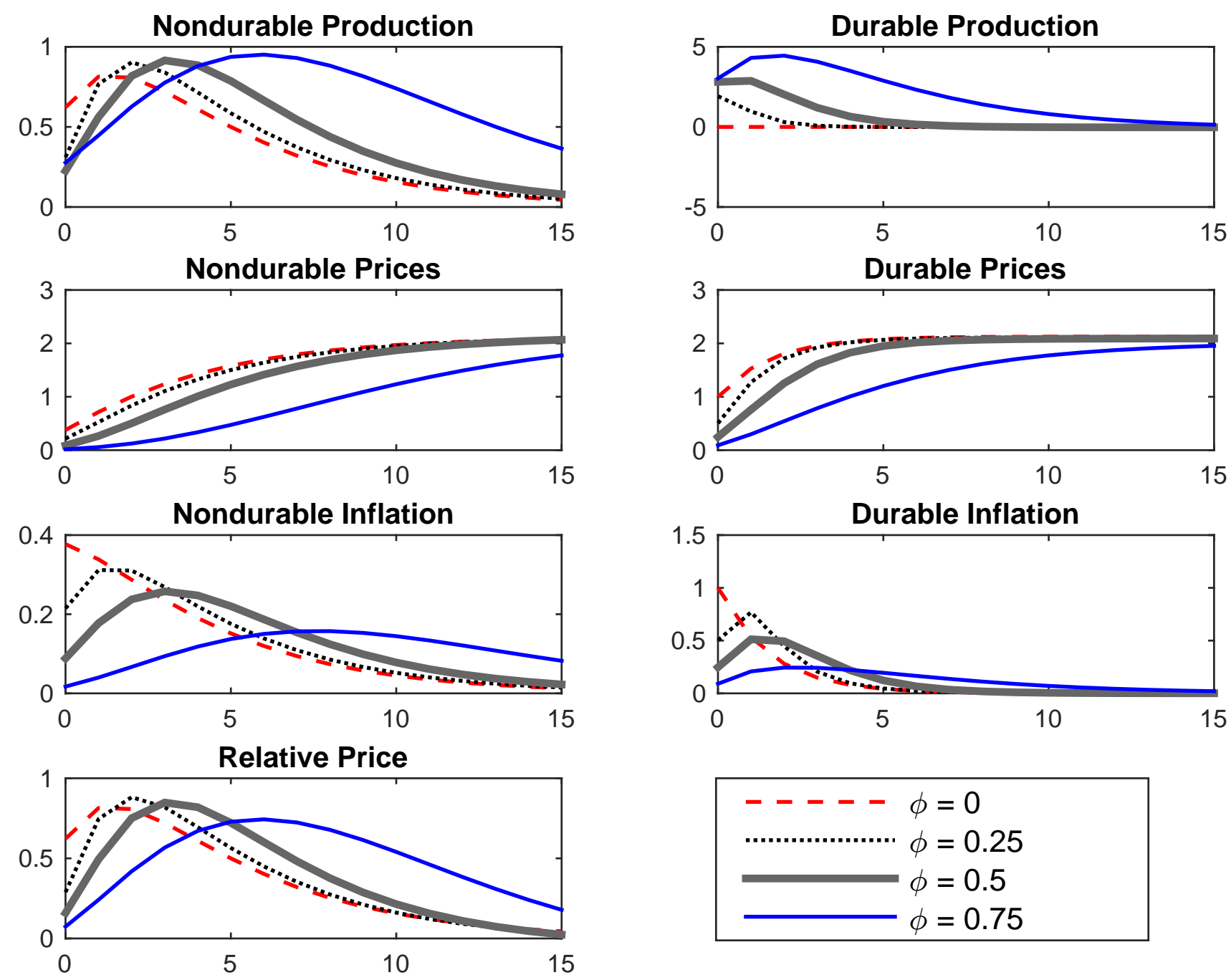

Figure 4: Model impulse responses: Firm-specific production factors and a persistent money-growth shock

Notes: The figure shows impulse responses to a one-percentage-point persistent increase in money growth. For nondurable and durable inflation, the units are percentage-point deviations from the steady state. For the other variables, the units are percentage deviations from the steady state. 

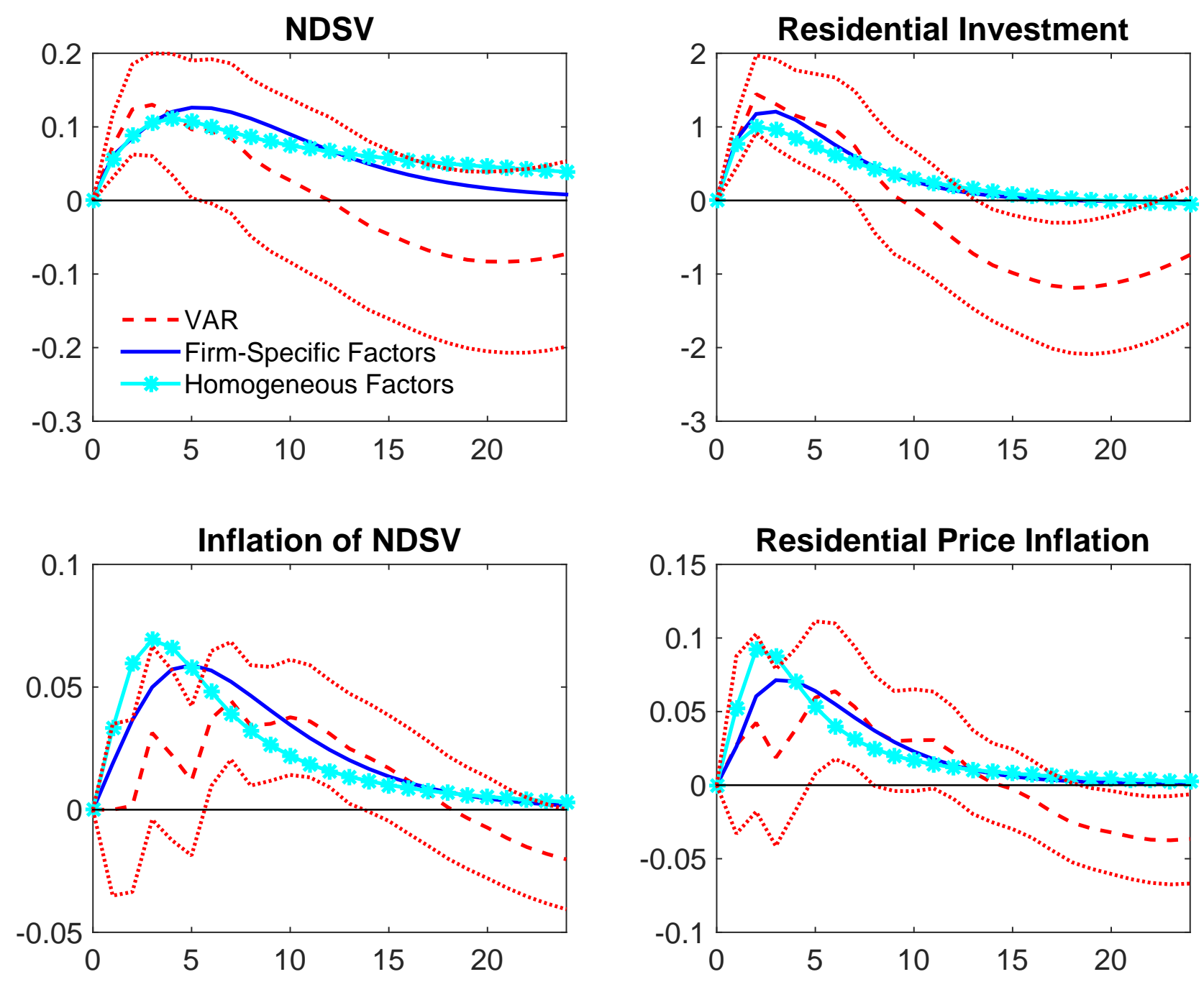

Figure 5: Comparison of model-implied and VAR impulse responses (money-growth rule)

Notes: The figure compares the VAR responses and the model-implied responses when production factors are firm-specific and monetary policy takes the form of the money-growth rule. The figure also shows the model-implied responses when production factors are homogeneous. The units for the variables are percentages for the sectoral output series and percentage points for the sectoral inflation series. Dotted lines are 95 percent confidence intervals for the VAR responses. 

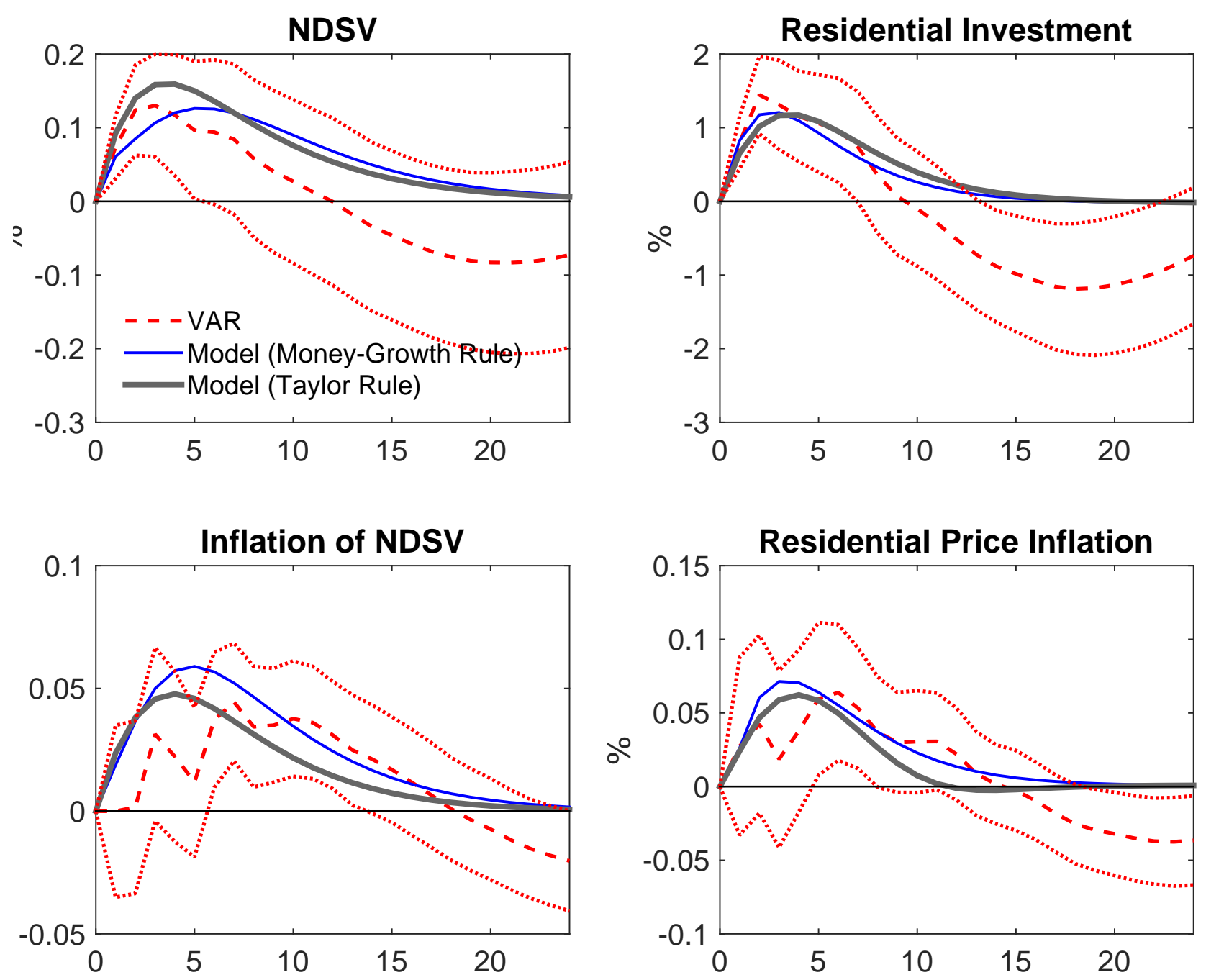

Figure 6: Comparison of model-implied and VAR impulse responses (interest-rate rule)

Notes: The figure compares the VAR responses and the model-implied responses when production factors are firm-specific and monetary policy takes the form of the interest-rate rule. The units for the variables are percentages for the sectoral output series and percentage points for the sectoral inflation series. Dotted lines are 95 percent confidence intervals for the VAR responses. 

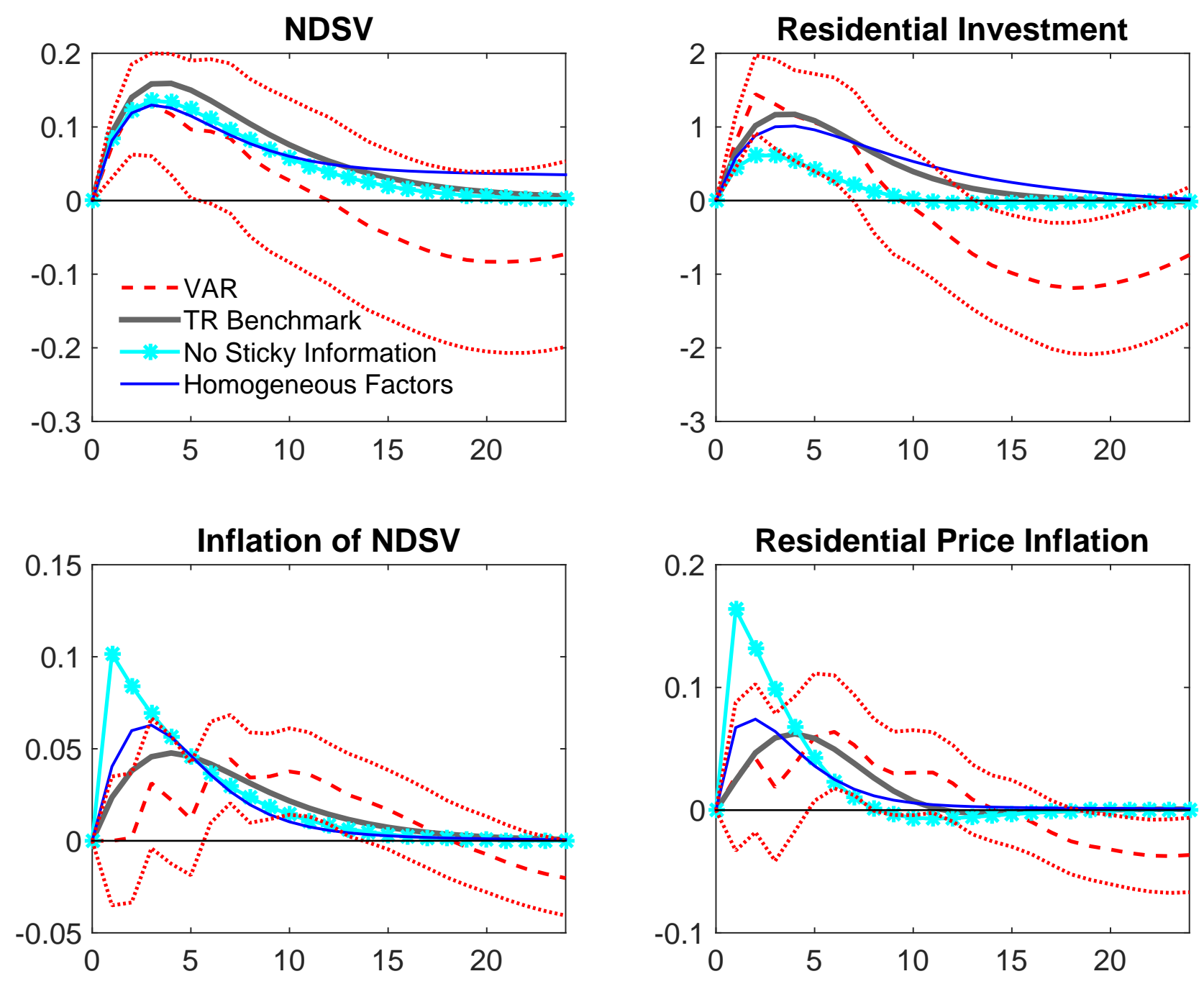

Figure 7: The roles of sticky information and firm-specific production factors (interest-rate rule)

Notes: The figure shows how the model-implied responses differ from the benchmark when either sticky information or firm-specific production factors is removed. Monetary policy takes the form of the interest-rate rule. Thick solid lines are the benchmark responses under the Taylor rule, thin solid lines show the case where production factors are homogeneous, and lines with asterisks indicate the case where there is no sticky information in the model but the prices of both goods are assumed to be equally sticky. As with other figures, VAR responses and 95 percent confidence intervals are shown by dashed and dotted lines, respectively. The sectoral output series and the sectoral inflation series are expressed in percentages and percentage points, respectively. 


\section{Technical Appendix}

\section{A.1 Log-Linearized Pricing Equation}

Let lower-case letters denote percentage deviations from steady-state values. To derive the pricing equation in each sector, first log-linearize (11) and (17):

$$
\begin{aligned}
p_{j, t, 0}^{*}(z) & =\left(1-\beta \theta_{j}\right) \sum_{i=0}^{\infty}\left(\theta_{j} \beta\right)^{i} \mathbb{E}_{t}\left[m c_{j, t+i}(z)\right], \\
m c_{j, t+i}(z) & =w_{j, t}(z)+\alpha n_{j, t}(z)
\end{aligned}
$$

Then,

$$
\begin{aligned}
p_{j, t, 0}^{*}(z) & =\left(1-\beta \theta_{j}\right) \sum_{i=0}^{\infty}\left(\theta_{j} \beta\right)^{i} \mathbb{E}_{t}\left[\omega y_{j, t+i}(z)-m u_{c, t+i}+p_{c, t+i}\right] \\
& =\left(1-\beta \theta_{j}\right) \sum_{i=0}^{\infty}\left(\theta_{j} \beta\right)^{i} \mathbb{E}_{t}\left[-\varepsilon \omega\left(p_{j, t, 0}^{*}(z)-p_{j, t+i}\right)+\omega y_{j, t+i}-\lambda_{t+1}\right] .
\end{aligned}
$$

Here, we used (2) and (9) in the first line and (8) in the second line. After shifting $p_{j, t, 0}^{*}(z)$ from the right-hand side to the left-hand side, it is straightforward to derive

$$
p_{j, t, 0}^{*}=\left(1-\theta_{j} \beta\right) m c_{j, t}^{f}+\theta_{j} \beta \mathbb{E}_{t} p_{j, t+1}^{*} \text { for } j=c, x
$$

where

$$
m c_{j, t}^{f} \equiv-\frac{1}{1+\varepsilon \omega} \lambda_{t}+\frac{\varepsilon \omega}{1+\varepsilon \omega} p_{j, t}+\frac{\omega}{1+\varepsilon \omega} y_{j, t} .
$$

Notice that the household's first-order conditions with respect to $C_{t}$ and $X_{t}$ yield

$$
\Gamma_{t}=\frac{P_{x, t}}{P_{c, t}} M U_{t}^{c}=P_{x, t} \Lambda_{t}
$$

where $\Gamma_{t}$ and $\Lambda_{t}$ are the Lagrange multipliers on (1) and the budget constraint, respectively. To obtain equation (21), substitute equation (23) and a log-linearized version of equation (24) into equation (22) with $\theta_{x}=0 .{ }^{26}$

$$
p_{x, t, 0}^{*}=p_{x, t}+\frac{1}{1+\varepsilon \omega}\left(\omega x_{t}-\gamma_{t}\right)
$$

\footnotetext{
${ }^{26}$ Equation (14) is the case without sticky information.
} 


\section{A.2 Two-Sector Dual-Stickiness Model with Heterogeneous Fac- tors}

\section{Log-linearized system}

The equilibrium is determined by the system of equations (1) through (11), as well as (18) and (19), the definition of the aggregate price level, $P_{t}=M_{t} / Y_{t}$, the definitions of marginal utilities, $M U_{t}^{C}=\partial u\left(C_{t}, D_{t}\right) / \partial C_{t}, M U_{t}^{D}=\partial u\left(C_{t}, D_{t}\right) / \partial D_{t}$, and the definition of the Lagrange multiplier on the budget constraint, $\Lambda_{t}{ }^{27}$ The endogenous variables are $\left\{D_{t}, X_{t}, C_{t}, Y_{t}, M U_{t}^{C}, M U_{t}^{D}\right.$, $\left.\Lambda_{t}, \Gamma_{t}, P_{j, t}, Q_{j, t}, P_{j, t, k}^{*}, M C_{j, t}^{f}, P_{t}\right\}$ and $M_{t}$ is exogenously determined by the money-growth rule.

The utility and production functions take the following functional forms:

$$
\begin{aligned}
u(C, D) & =\frac{\sigma}{\sigma-1}\left[\left\{\psi_{c} C^{\frac{\rho-1}{\rho}}+\left(1-\psi_{c}\right) D^{\frac{\rho-1}{\rho}}\right\}^{\frac{\rho}{\rho-1}}\right]^{\frac{\sigma-1}{\sigma}}, \\
v(N) & =\psi_{n} \frac{\eta}{\eta+1} N^{\frac{\eta+1}{\eta}} \\
F(K, N) & =A K^{\alpha} N^{1-\alpha}
\end{aligned}
$$

The system of log-linearized equations can be expressed as below.

$$
\begin{aligned}
d_{t} & =\delta x_{t}+(1-\delta) d_{t-1}, \\
\gamma_{t} & =[1-\beta(1-\delta)] m u_{d, t}+\beta(1-\delta) \mathbb{E}_{t}\left[\gamma_{t+1}\right], \\
\gamma_{t} & =p_{x, t}-p_{c, t}+m u_{c, t}, \\
\lambda_{t} & =m u_{c, t}-p_{c, t}, \\
m u_{c, t} & =u_{c c} c_{t}+u_{c d} d_{t}, \\
m u_{d, t} & =u_{d c} c_{t}+u_{d d} d_{t}, \\
m_{t} & =p_{t}+y_{t}, \\
m c_{j, t}^{f} & =-\frac{1}{1+\varepsilon \omega} \lambda_{t}+\frac{\varepsilon \omega}{1+\varepsilon \omega} p_{j, t}+\frac{\omega}{1+\varepsilon \omega} y_{j, t} \text { for } j=c, x, \\
p_{j, t}^{*} & =\left(1-\theta_{j} \beta\right) m c_{t}^{f}+\theta_{j} \beta \mathbb{E}_{t} p_{j, t+1}^{*} \text { for } j=c, x, \\
q_{j, t} & =(1-\phi) \sum_{k=0}^{\infty} \phi^{k} \mathbb{E}_{t-k} p_{j, t}^{*} \text { for } j=c, x, \\
p_{j, t} & =\theta_{j} p_{j, t-1}+\left(1-\theta_{j}\right) q_{j, t} \text { for } j=c, x, \\
y_{t} & =\kappa_{c} c_{t}+\left(1-\kappa_{c}\right) x_{t},
\end{aligned}
$$

\footnotetext{
${ }^{27}$ We include the Lagrange multipliers in the system for ease of exposition.
} 


$$
\begin{aligned}
p_{t} & =\kappa_{c} p_{c, t}+\left(1-\kappa_{c}\right) p_{x, t}, \\
\Delta m_{t} & =\rho_{m} \Delta m_{t-1}+\varepsilon_{t}
\end{aligned}
$$

where

$$
\begin{aligned}
\kappa_{c} & \equiv \frac{P_{c, s s} C_{s s}}{P_{c, s s} C_{s s}+P_{x, s s} X_{s s}}, \\
\omega & \equiv \frac{\alpha+\eta^{-1}}{1-\alpha}, \\
u_{c c} & \equiv\left(\rho^{-1}-\sigma^{-1}\right) \frac{1}{1+\frac{1-\psi_{c}}{\psi_{c}}\left(\frac{D_{s s}}{C_{s s}}\right)^{\frac{\rho-1}{\rho}}}-\rho^{-1}, \\
u_{c d} & \equiv\left(\rho^{-1}-\sigma^{-1}\right) \frac{1}{1+\left\{\frac{1-\psi_{c}}{\psi_{c}}\left(\frac{D_{s s}}{C_{s s}}\right)^{\frac{\rho-1}{\rho}}\right\}^{-1}}, \\
u_{d c} & \equiv\left(\rho^{-1}-\sigma^{-1}\right) \frac{1}{1+\frac{1-\psi_{c}}{\psi_{c}}\left(\frac{D_{s s}}{C_{s s}}\right)^{\frac{\rho-1}{\rho}}}, 1 \\
u_{d d} & \equiv\left(\rho^{-1}-\sigma^{-1}\right) \frac{1+\left\{\frac{1-\psi_{c}}{\psi_{c}}\left(\frac{D_{s s}}{C_{s s}}\right)^{\frac{\rho-1}{\rho}}\right\}^{-1}}{1-\rho^{-1} .}
\end{aligned}
$$

In equations (29) and (30), we defined $p_{j, t}^{*} \equiv p_{j, t, 0}^{*}$ and used the fact that $p_{j, t, k}^{*}=\mathbb{E}_{t-k} p_{j, t}^{*}$. The system of log-linearized equations with lagged expectations can be solved by algorithms developed by Meyer-Gohde (2009) and Wang and Wei (2006). The sticky-information model has an infinite number of lagged expectations. These methods truncate the lags at a sufficiently large finite value and solve a finite-order lagged expectations model.

\section{A.3 The Model with Firm-Specific Factors and One-Period Lagged Decisions}

The model in Section 5 imposes some additional restrictions on the timing of agents' decisions. These assumptions ensure that model-implied responses to a monetary policy shock in the initial period are zero as in the VAR analysis. First, nominal aggregate demand in the economy is determined by the money balance from the previous period:

$$
M_{t-1}=P_{c, t} C_{t}+P_{x, t} X_{t}
$$


Second, the representative household and firms that are not constrained by sticky prices make decisions one period in advance. Under these additional assumptions, log-linearized optimality conditions (25), (30) and (22) are replaced by the following conditions:

$$
\begin{array}{r}
\gamma_{t}=[1-\beta(1-\delta)] m u_{d, t}+\beta(1-\delta) \mathbb{E}_{t-1}\left[\gamma_{t+1}\right] \\
q_{j, t}=(1-\phi) p_{j, t}^{*}+(1-\phi) \sum_{k=2}^{\infty} \phi^{k-1} \mathbb{E}_{t-k}\left[p_{j, t}^{*}\right] \\
p_{j, t}^{*}=\left(1-\theta_{j} \beta\right) m c_{j, t}^{f}+\theta_{j} \beta \mathbb{E}_{t-1}\left[p_{j, t+1}^{*}\right]
\end{array}
$$

\section{A.4 The Model with Interest-Rate Rule, Firm-Specific Factors and One-Period Lagged Decisions}

Households' problem in Section 5.1 is shown below.

$$
\left.\max _{\left\{\begin{array}{c}
C_{t+i}, D_{t+i}, X_{t+i}, \\
S_{t+i}, N_{j, t+i}(z)
\end{array}\right.}\right\}_{i=0}^{\infty} \mathbb{E}_{t-1} \sum_{i=0}^{\infty} \beta^{i}\left\{u\left(C_{t}-\varrho_{c} C_{t-1}, D_{t+i}\right)-\sum_{j=C, X} \int_{0}^{1} \nu\left(N_{j, t+i}(z)\right) d z\right\}
$$

subject to

$$
\begin{array}{r}
P_{c, t} C_{t}+P_{x, t} X_{t}+S_{t} \leq \sum_{j=C, X} \int_{0}^{1} W_{j, t}(z) N_{j, t}(z) d z+\left(1+i_{t-1}\right) S_{t-1}+\Pi_{t}+T_{t} \\
D_{t}=(1-\delta) D_{t-1}+\left\{1-h\left(\frac{X_{t}}{X_{t-1}}\right)\right\} X_{t} .
\end{array}
$$

Again, let $\Lambda_{t}$ and $\Gamma_{t}$ denote the Lagrange multipliers on the budget constraint and the law of motion of durable goods, respectively. Log-linearized equilibrium conditions, (26) and (27), are replaced by the following two conditions:

$$
\begin{array}{r}
\gamma_{t}=p_{x, t}+\lambda_{t}+(1+\beta) \psi_{h} x_{t}-\psi_{h} x_{t-1}, \\
m u_{c, t}=\beta \varrho_{c} \mathbb{E}_{t-1}\left[m u_{c, t+1}\right]+\left(1-\beta \varrho_{c}\right)\left(p_{c, t}+\lambda_{t}\right) .
\end{array}
$$

Moreover, the following optimal savings decision replaces the quantity equation, (28).

$$
\lambda_{t}=i_{t}+\mathbb{E}_{t-1}\left[\lambda_{t+1}\right]
$$

Equilibrium conditions for producers are the same as in Section A.3. 


\section{Data Appendix}

\section{Sources}

We obtained the following data series from the National Economic Accounts Data from the U.S. Bureau of Economic Analysis (http://www.bea.gov/).

\begin{tabular}{|l|c|}
\hline Series & Table \\
\hline Real GDP, quantity index & 1.1 .3 \\
\hline Gross Domestic Product & 1.1 .5 \\
\hline Price Indexes for Gross Domestic Product & 1.1 .4 \\
\hline
\end{tabular}

Federal funds rates and the seasonally adjusted Divisia monetary aggregate index for MZM are from the Federal Reserve Economic Data (FRED, http://research.stlouisfed.org/fred2/). For the commodity price index, we use the index for agricultural raw materials (00176BXDZF) in the International Financial Statistics (IFS) of the International Monetary Fund (IMF).

\section{Construction of GDP and Price Data Series}

Following Whelan (2002), we use the Tornqvist approximation to construct the series for NDSV. To do this, we combine real nondurable goods and real services using the following formula:

$$
\frac{\Delta Y_{t}}{Y_{t-1}}=\theta_{t} \frac{\Delta X_{t}}{X_{t-1}}+\left(1-\theta_{t}\right) \frac{\Delta Z_{t}}{Z_{t-1}},
$$

where $X$ is a component of $Y, Z$ is a series excluding $X$ from $Y$, and $\theta_{t}$ is the average of nominal expenditure shares of $X$ in period $t$ and $t-1$. We apply the same procedure to construct the price series for NDSV. 